\title{
Guinea: Staff Report for the 1999 Article IV Consultation and Request for the Third Annual Arrangement Under the Enhanced Structural Adjustment Facility
}

This report was prepared by a staff team of the International Monetary Fund following discussions with the officials of Guinea on economic developments and policies. The report was then considered by the IMF's Executive Board in the context of the IMF's periodic consultation with Guinea, as required under Article IV of the IMF Articles of Agreement. The views expressed in the staff report itself are those of the staff team and do not necessarily reflect the views of the Executive Board of the IMF or of the authorities of Guinea; a supplementary statement by IMF staff may also be included. The views of the Executive Board as expressed in the discussion of the Article IV consultation report and as summarized in a Public Information Notice (PIN) are also included. In addition, a statement by the member country authorities may be appended. Further background documentation prepared by IMF staff for the consultation may be published separately at a later date. The policy of publication of Article IV staff reports allows for the deletion of market sensitive information.

This Article IV staff report is published—both in hard copy and on the IMF's website (http://www.imf.org) - as part of a pilot project. To assist the IMF in evaluating the pilot project for release of Article IV staff reports, reader comments on the staff report are invited prior to October 5, 2000, and may be sent by e-mail to Pilotproject@imf.org.

Copies of this report are available to the public from

International Monetary Fund • Publication Services

700 19th Street, N.W. • Washington, D.C. 20431

Telephone: (202) 623-7430 • Telefax: (202) 623-7201

Telex (RCA): 248331 IMF UR

E-mail: publications@imf.org

Internet: http://www.imf.org

Price: $\$ 15.00$ a copy

International Monetary Fund

Washington, D.C. 


\title{
INTERNATIONAL MONETARY FUND
}

\section{GUINEA}

\section{Staff Report for the 1999 Article IV Consultation and Request for the Third Annual Arrangement Under the Enhanced Structural Adjustment Facility}

\author{
Prepared by the African Department \\ (In consultation with the Legal, Monetary and Exchange Affairs, \\ Policy Development and Review, Statistics, and Treasurer's Departments) \\ Approved by Ernesto Hernández-Catá and Ishan Kapur
}

December 8, 1999

Contents

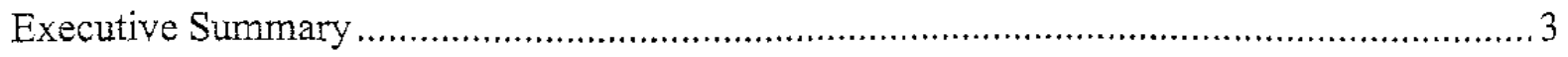

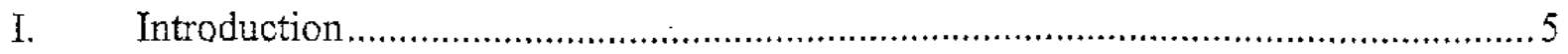

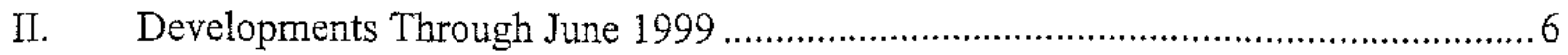

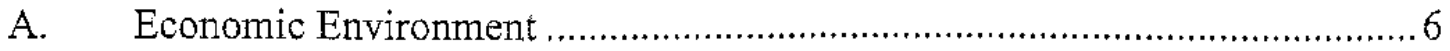

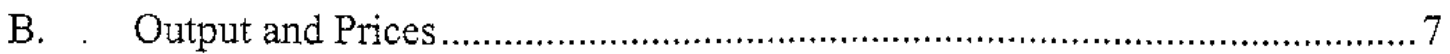

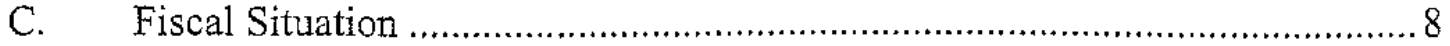

D. Monetary Developments .......................................................................... 10

E. External Sector and Debt ......................................................................... 11

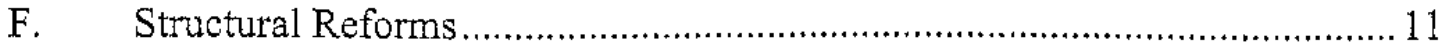

III. Report on the Discussions and the 1999-2000 Program ...........................................12

A. Prior Actions to Program Discussions .................................................... 12

B. The 1999/2000 Economic Program ………................................................. 14

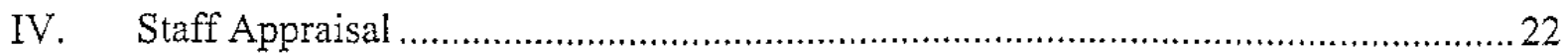

Boxes

1. Exchange Market Unification Through Foreign Exchange Auctions .......................9

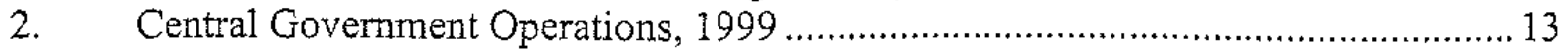

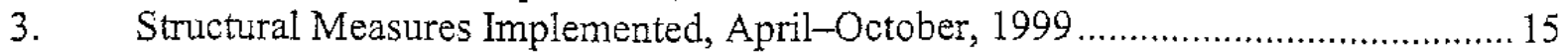

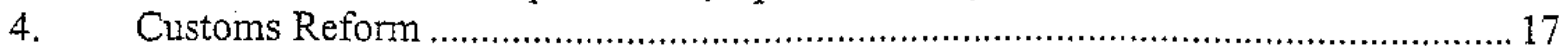

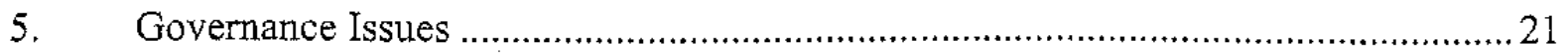


Figures

1. Official and Parallel Exchange Rates, January 1998-October 1999 ........................26

2. Effective Exchange Rates, January 1992-August 1999 ..........................................2

Tables

1. Selected Economic and Finance Indicators, 1997-2001 .......................................28

2. Gross Domestic Product at Constant 1994 Prices by Sectors, 1997-2001...............29

3. Gross Domestic Product at Current Prices by Demand Components, 1997-2001 ....30

4. Financial Operations of the Central Government, 1997-2001 ……........................31

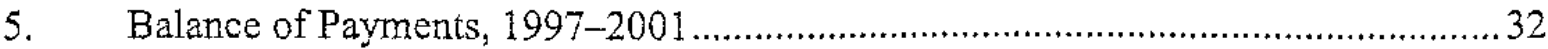

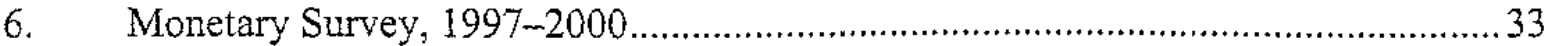

7. Indicators of Fund Credit and Debt Servicing, 1995-2006 .....................................34

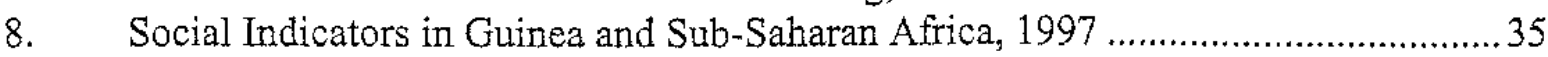

Appendices

1. Third Annual Arrangement Under the Enhanced Structural Adjustment Facility ....36 Attachment

Letter of Intent and Memorandum of Economic and Financial Policies

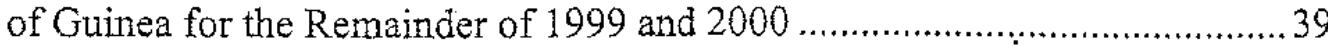

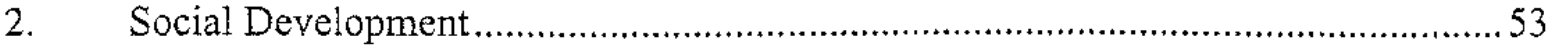

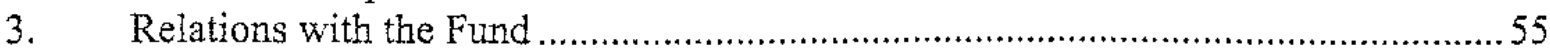

4. Relations with the World Bank Group ……........................................................5

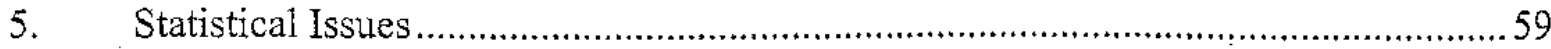




\section{EXECUTIVE SUMMaRY}

\section{Background}

A three-year arrangement under the ESAF, in an amount equivalent to SDR 70.80 million (90 percent of quota), was approved on January 13, 1997. The second annual arrangement expired on December 31, 1998.

\section{Recent economic and financial developments}

- Economic developments in the second half of 1998 and first half of 1999 were influenced by external events: a sharp fall in the prices of Guinea's main exports, regional insecurity, and presidential elections in December 1998.

- Real GDP rose by 4.5 percent in 1998 with only the primary sector showing some dynamism. Real growth is expected to slow to 3.7 percent in 1999 , with new gold mining activity being more than offset by a slowdown in the service sector, particularly trade. The current account deficit narrowed somewhat in 1998 and 1999.

- Fiscal developments reflected the difficult external and domestic environment. Falling revenue in 1998 was somewhat offset by expenditure compression, but there was a large expenditure overhang into 1999. The continuing conflict in Sierra Leone in 1999 required large expenditures by Guinea to support ECOMOG peacekeeping forces.

- Large fiscal overruns in early 1999 were financed by borrowing from the central bank. M2 grew rapidly in the first four months of the year and net foreign assets fell.

- The currency depreciated in 1998 and 1999, with the spread between the official rate and parallel rate remaining at 5-10 percent.

- In mid-1999, the government began to take strong actions to stabilize the macroeconomic situation, including adopting a new budget and structural reforms to strengthen expenditure control. These actions began to have an impact in August, as the fiscal situation improved, M2 stabilized and net foreign assets increased.

- A foreign exchange auction was implemented at the central bank to begin to unify the exchange rate. 


\section{The 1999-2000 program}

- The program envisages real GDP gowth increasing to 5 percent in 2000 , with economic activity picking up in the primary sector and in mining. The current account deficit is expected to widen to 6.3 percent of GDP because of imports associated with investment.

- Revenue is expected to rise from 10.4 percent of GDP in 1999 to 11.5 percent in 2000. The primary domestic surplus for 2000 is projected at 2.7 percent.

- Implementation of customs reform measures are essential to meeting program objectives in 2000 .

- Monetary policy will aim at rebuilding central bank reserves, while providing sufficient credit to the private sector to sustain real growth. A floating exchange rate will be maintained and the exchange rate unified.

- Banking reform will continue, with an audit of the central bank and restructuring of microcredit institutions.

- Other structural reforms are focused on budgetary operations, public enterprise reforms, and reform of the social security system.

- Governance issues remain a concern. A anticorruption commission is to be established by end 1999.

- Social indicators are very weak in Guinea. The authorities indicated that much of the groundwork for a PRSP has been done and that they were prepared to move ahead in the context of the HIPC initiative.

In the financial sector, Guinea appears well prepared to confront the Y2K problem. 


\section{INTRODUCTION}

1. The 1999 Article IV consultation discussions were held in Conakry during the period September 7-22, and November 8-12, 1999. In addition, discussions on an economic and financial program for Guinea that could be supported by a third annual arrangement under the Enhanced Structural Adjustment Facility (ESAF) were continued. ${ }^{1}$ These discussions were initiated during January 26, 1999-February 9, 1999 and resumed during May 4-13, 1999, but they were not completed because of serious macroeconomic difficulties, as described below.

2. A three-year arrangement under the ESAF, in an amount equivalent to SDR 70.80 million (90 percent of quota), ${ }^{2}$ was approved on January 13, 1997 (EBS/96/204; $12 / 27 / 96$ ). In the attached letter from the Minister of Economy and Finance, dated December 7, 1999, Guinea requests the third annual arrangement under the ESAF covering the program period from October 1, 1999 to September 30,2000, in an amount equivalent to SDR 23.6 million ( 30 percent of quota), in support of the program outlined in both the memorandum of economic and financial policies (MEFP) (Appendix I, Attachment) and in the policy framework paper (PFP) (EBD/99/134). Because the commitment period of the threeyear ESAF arrangement will expire on January 12,2000, which is prior to the date envisaged for the disbursement of the second and third loans under the third annual arrangement, the authorities have requested an extension of the three-year commitment period until January 12,2001 . The Guinean authorities have agreed to the publication of the staff report, letter of intent, and PFP. A preliminary document on the Initiative for Highly Indebted Poor Countries (HIPC) will be presented (forthcoming).

${ }^{1}$ The staff team for the September mission consisted of Mr. Plant (head-AFR), Ms. Devaux (AFR), Mr. Herderschee (PDR), Ms. Adenauer (AFR), Mr. Walliser (AFR-EP), and Ms. Niaré (assistant-AFR). Mr. Le Bouder, the Fund's Senior Resident Representative in Guinea, played a key role throughout the discussions. Mr. Konan, Advisor to the Executive Director for Guinea, participated in the discussions. The mission worked closely with teams from the World Bank, the European Union, and the African Development Bank. The mission met with President Conté, the Prime Minister, and the Ministers of Finance, Planning, Social Affairs, Mines, Transport, Health, Primary and Secondary Education, Justice, and Security, as well as the Governor of the Central Bank of the Republic of Guinea. The mission also discussed the economic situation with representatives of Parliament, labor unions, the business community, nongovernmental organizations, donors, commercial banks, and Islamic religious leaders. In November, the staff team consisted of Mr. Plant and Ms. Adenauer.

${ }^{2}$ All amounts are expressed in percent of ninth review quota. 
3. Guinea is on the standard 12-month consultation cycle. The 1998 Article IV consultation with Guinea was concluded on April 3, 1998 (EBS/98/54;3/20/98). ${ }^{3}$ On that occasion, Directors commended the authorities for their continued efforts to advance economic reforms and stressed that steadfast implementation of sound financial policies and structural reforms was vital to facilitate more rapid growth. They urged continued pursuit of fiscal consolidation, including a prompt return from cash management to proper budgetary procedures and establishment of greater transparency in public resource management. Directors stressed the need to rein in inflation through a tighter monetary policy and urged that the central bank limit its interventions in the foreign exchange market.

4. As of September 30, 1999, Guinea's outstanding use of Fund resources amounted to SDR 86.6 million, equivalent to 80.8 percent of quota. Assuming full disbursement of the loans under the third annual ESAF arrangement, and taking into account scheduled repayments over this period, Guinea's financial obligations to the Fund would amount to SDR 102.4 million or 95.6 percent of quota at end-December 2000 (Table 7). Guinea's structural reform program continues to receive support from the World Bank group and other donors. Guinea has accepted the obligations of Article VIII. Guinea's relations with the Fund and the World Bank Group are summarized in Appendices III and IV, respectively. A draft background section to the Public Information Notice is included in Appendix VI.

5. Overall, the quality, coverage, and timeliness of statistical information in Guinea remain poor (Appendix V). There are important deficiencies in the areas of national accounts, prices, and balance of payments that hamper effective surveillance and complicate policy analysis. Fiscal and monetary data are adequate for program design and monitoring. The authorities have requested further technical assistance to supplement their efforts to address these weaknesses. This request is being reviewed by the Fund. As improvements to the quality of data are made with the help of technical assistance, there may be significant revisions to past data.

\section{Developments Through June 1999}

\section{A. Economic Environment}

6. Economic developments in the second half of 1998 and first half of 1999 were influenced by external events in three important ways. First, the Asian crisis triggered a sharp

\footnotetext{
${ }^{3}$ The staff had expected to have the 1999 Article IV at the time of the midterm review of the third annual ESAF arrangement. When the program went off track, there were insufficient staff resources to field a separate Article IV mission. Guinea was presented at an informal country matters session in June 1999.
} 
fall in the demand for, and the prices of, Guinea's main export products-bauxite and alumina. As a result, mining sector revenue stagnated, and investor interest in the parastatal companies in the aluminum sector waned.

7. Second, the security situation in neighboring countries-Sierra Leone, GuineaBissau, and Liberia-required the government to increase its support of ECOMOG peacekeeping forces (the military branch of the Economic Community of West African States), reinforce the defense of its borders, and host an increasingly large number of refugees. ${ }^{4}$ Early in 1999, a peace settlement in Sierra Leone appeared in the offing, and thus the 1999 budget included sufficient financing for four-six months of ECOMOG support. In the event, the war continued, and Guinean troops are still stationed in Sierra Leone. Thus far, the current cease-fire is holding in Sierra Leone; however, incursions into Guinea from Liberia and Sierra Leone persist and thus the heightened surveillance of border regions continues.

8. Third, presidential elections were held in December 1998. In the run-up to the elections, imports fell off sharply-despite the dual holiday season (Christmas and Ramadan)-because of uncertainty about the impact of the elections on domestic stability. President Conté was elected in the first round of voting, but he did not name a new cabinet until March 1999. ${ }^{5}$ The combined effect of these external events was to curb economic activity and to exert pressure on an already tight budget, both by reducing revenue and by increasing expenditure.

\section{B. Output and Prices}

9. In 1998, real GDP rose by 4.5 percent, compared with 4.8 percent in 1997 , with only the primary sector showing some dynamism (Tables 1 and 2 ). In particular, the fishing sector enjoyed a record catch in 1998, thanks to the privatization of several fishing companies. Mining activity remained sluggish in the face of declining demand, despite an increase in gold production. The services sector was weak; imports decreased with a slowdown in the public investment program and a recovery in the domestic production of rice. Consumer prices rose by 5.1 percent, compared with 1.9 percent in 1997. (Table 1).

${ }^{4}$ There is disagreement about the number of refugees in Guinea, with estimates ranging from 300,000 to 1 million. (The population of Guinea is about 7 million people.) The uncertainty arises because many non-Guineans are hosted by their extended family, without being formally registered as refugees.

${ }^{5}$ Several days after the elections, the President's chief opponent, Alpha Condé, was arrested and charged with sedition. He remains in prison and has not yet been tried. His dossier is with the judicial system. 
10. Real GDP growth is expected to slow to 3.7 percent in 1999 (Tables 1 and 2). The primary sector expanded through June 1999 at a moderate pace, with growth in fishing activity slowing as fewer licenses were handed out and sectoral infrastructure capacity was strained. In contrast, the mining sector showed robust growth for the first six months of 1999 , as gold output grew rapidly, with new exporters establishing operations, and there was some rebound in bauxite and alumina production. The conflict in Sierra Leone continued to hamper trade throughout the first half of the year, restraining services sector growth. Average inflation in 1999 is projected to decline to 4.5 percent from 5.1 percent in 1998 , even though gasoline prices increased by 15-20 percent in early October, and the exchange rate depreciated rapidly in the fourth quarter owing to the institution of a foreign exchange auction at the central bank (see Box 1). The 12-month rate of inflation is expected to rise to 5.4 percent in December 1999, from 4.5 percent in 1998.

\section{Fiscal Situation}

11. Fiscal developments in 1998 reflected the difficult external and domestic environment. Revenue fell to 10.6 percent of GDP-0.6 percentage point lower than in 1997 - with taxes on mining activity growing by only 2.8 percent and taxes on international trade falling in nominal terms (Table 4). Current expenditure fell from 8.8 percent of GDP in 1997 to 8.3 percent of GDP in 1998 , while the primary surplus narrowed to 2.4 percent of GDP from 2.8 percent in 1997 . There was a marked slowdown in capital spending by the government, as external project lending dropped sharply. As a result, the overall fiscal deficit, excluding grants, improved from 5.9 percent of GDP in 1997 to 3.4 percent of GDP in 1998; including grants, the improvement in the deficit was from 2.9 percent of GDP to 0.7 percent.

12. Numbers alone do not tell the whole fiscal story for $\mathbf{1 9 9 8}$ and its legacy for 1999, because of a breakdown in budget discipline and the unconventional use of budgetary and accounting procedures by the authorities. In particular, some expenditure that had been committed in 1998 was postponed into 1999, while some payments were made without commitments. In some cases, the postponement reflected the usual process of belt tightening-consumption was delayed from one year to the next. In others, the postponement amounted to arrears, with consumption taking place in 1998 with or without corresponding commitments. This expenditure overhang from 1998 compounded problems encountered early in 1999 as a result of the failure of the computerized expenditure-monitoring system and the lack of a budget for 1999 during the first three months of the year. Furthermore, some accounting sleight of hand continued in 1999; for example, salaries were committed on the last day of the month but paid on the first day of the next month, so as to minimize the impact on end-of-month government borrowing. 


\section{Box 1. Exchange Market Unification Through Foreign Exchange Auctions}

Before September 1999, the foreign exchange market in Guinea was highly segmented. The official market was dominated by state enterprises and the donor community, which used two foreign-owned banks to convert foreign currency, and by large importers who bought the foreign exchange. On most days, the officially recorded exchange rate, announced by the central bank, reflected the average transaction rate offered by the two banks. Some exporters used the other five smaller banks, but supply of foreign exchange outside the two large banks was sporadic, and competition with the two larger banks was difficult.

The so-called parallel market actually has official status. It consists of more than 50 exchange bureaus and their agents, accredited by the central bank. The exchange rate premium offered in this market relative to the official rate was 4-6 percent through mid-1998, but in late 1998 and early 1999 , the spread between the official rate and the parallel rate began to widen as the economic situation became increasingly tenuous. The authorities appeared to be propping up the official rate-either by "jawboning" or by keeping some transactions outside the rate's calculation-with the effect of diverting more foreign exchange demand from official channels. By early 1999 the parallel market accounted for about 60-70 percent of the foreign exchange market, while the spread between the official and parallel rates reached as much as 15 percent in the second half of 1998 and averaged about 10 percent in the first eight months of 1999. Market segmentation became more pronounced, leading to foreign exchange "shortages," while operators who had access to foreign exchange at official rates realized substantial rents. The official foreign exchange market, and the entire banking system, became increasingly cartelized-supplies of foreign exchange to small banks by exporters dried up, thus giving a marked competitive advantage to the two large banks.

After much debate, the authorities decided to unify the exchange market by implementing a foreign exchange auction at the central bank, which began on September 1, 1999. State enterprises are required to auction their foreign exchange proceeds at this market, and other exporters, donors and official lenders are encouraged to use it. Initially a highest bid auction was used, but the authorities were worried about the resulting pace of depreciation and unilaterally changed the auction modalities to a nontransparent average bid system. After discussion with Fund staff in November, it was agreed that a marginal price auction would be used; banks submit price/quantity bids and the available foreign exchange is sold to the highest bidders but at the lowest price that assures all foreign exchange offered at the auction is sold. A two percent premium is charged to banks who make outlying bids.

The result since September has been a depreciation of the Guinean franc in both the official and parallel markets and a narrowing of the spread between the two rates. However, the auction has encountered some difficulties. Donors have been slow to shift their foreign exchange to the auction and, until November, under the pressure from the large banks, the government did not enforce the requirement that state-owned enterprises sell their foreign exchange at the auction. As a result, the two foreign-owned banks held onto their dominant positions. In November, the government renewed its commitment to make the auction work and to ensure that parastatals use it. Although it will take some time for the rigidities and imperfections in the foreign exchange market and the banking system to be worked through, the auction appears to have introduced a degree of competitiveness back into what was in effect a cartelized system.

The present exchange arrangement represents an improvement over the situation before the auction system was instituted, but it involves a multiple currency practice arising from the contemporaneous application of the official rate and commercial bank rates. 
13. These difficulties came to a head when the bills from 1998 came due and when government paid April salaries in April: borrowing from the banking system ballooned to 1.4 percent of GDP by end-April, even though only 0.3 percent of GDP had been programmed for the entire year. The budget situation was further aggravated by the continuing contributions to ECOMOG. These had been budgeted at GF 10 billion ( 0.2 percent of GDP), with the hope that the conflict would be resolved early in 1999, but the amount needed for the year had increased to GF 18 billion ( 0.4 percent of GDP) by end-April. Also, additional funding was needed to resolve Year 2000 (Y2K) problems, customs revenue was weak and there was a shortage of external financing. Thus, a staff team visited Conakry in May and worked with the authorities to craft a new budget plan, under which increased military and Y2K spending would be partially absorbed by cuts on nonpriority and capital expenditure.

\section{Monetary Developments}

14. M2 grew by 11 percent during the first 11 months of 1998 , with government borrowing from the banking system increasing by 12.8 percent of beginning-of-period money and net foreign assets of the banking system declining by 8.8 percent on the same basis. This situation was reversed in December with the disbursement of aid from the World Bank and the European Union that had been delayed; the money supply fell, and money growth for the year was only 6.1 percent, as government credit declined by 3.5 percent of beginning-of-period money and net foreign assets increasing by 5.6 percent of beginning-of-period money (Tables 1 and 6). The net foreign asset position of the central bank deteriorated from US\$118 million at end-December 1997 to US\$72 million at end-November 1998, before it recovered to US\$114 million at end-December. Credit to the private sector credit grew by 17 percent in 1998 .

15. The positive developments recorded at end-1998 could not be sustained during the first four months of 1999, given the surge in government borrowing related to the lack of fiscal control. Broad money grew by 9 percent through end-April, central bank reserves fell by US $\$ 33$ million, and credit to the private sector shrank. However, by end-June 1999, with fiscal control beginning to be reasserted, the situation stabilized. Credit to the government declined, growth in M2 stopped, and there were small increases in net foreign assets and private sector credit.

16. The official exchange rate of the Guinean franc depreciated by 5 percent during the second half of 1998, and by another 14 percent in the first six months of 1999 (Figure 1). The spread between the official rate and the parallel rate widened to as much as 15 percent in November 1998 and remained between 8 percent and 10 percent during the first half of 1999 . The real effective exchange rate fell markedly in 1998 , but appears to have stabilized in 1999 (Figure 2). The authorities' policy in 1998-99 was to accept a nominal depreciation, but often the official rate was administratively manipulated to keep it from slipping too rapidly (Box 1). The central bank did not intervene in the foreign exchange market to augment its reserves, arguing that in the face of the wide discrepancy between the 
official and parallel rates, banks were not offering foreign exchange in the interbank market. Nonproject donor aid vanished in the first six months of 1999 and official foreign exchange became increasingly scarce, leading to more segmentation of the official and parallel markets; the volume of transactions in the parallel market expanded to 60-70 percent of the total.

\section{E. External Sector and Debt}

17. The current account deficit, excluding public transfers, narrowed as a share of GDP from 6.3 percent in 1997 to 6 percent in 1998 and is expected to decline to 5.9 percent in 1999 (Table 5). With the establishment of new gold mines, the merchandise trade surplus has grown from US\$88 million in 1997 to a projected US\$174 million in 1999, in spite of the increased imports of goods and services associated with the opening of the mines and related income payments.

18. There was a sharp decline in the capital account surplus in 1998. In the run-up to the presidential elections in December, private investors hesitated, while public investment stalled because the tight budget made it difficult for the government to put up the domestic matching funds required to mobilize foreign project aid. In addition, budgetary assistance in 1998 was markedly lower than in 1997. In 1999, private investment has continued to be weak, especially as investments in gold mining have largely been completed; however, projectrelated external loans have picked up with the reinvigoration of the public investment program-disbursements could be almost 50 percent higher than in 1998. Amortization payments due increased, but payments effected declined as a result of debt reschedulings and some accumulation of arrears to creditors with whom no rescheduling agreements have yet been negotiated.

19. Early in 1999, Guinea had arrears to some Paris Club creditors because some payments had been postponed from 1998 in the face of budgetary difficulties and because of problems with the debt-management system. Arrears on nonreschedulable debt were cleared by end-April, and the second tranche (covering maturities due in 1998) of the 1997 Paris Club rescheduling agreement was implemented. The debt-management system has been strengthened. Guinea continues to have arrears with Russia and several non-Paris Club creditors; discussions with Russia recommenced in late October while the non-Paris Club arrears are also under negotiation.

\section{F. Structural Reforms}

20. The authorities have made significant progress in restoring the health of the banking system over the past 18 months. Of the seven banks operating in Guinea, all but one is in good shape, observing prudential norms on solvency and asset quality. Two banks, for which restructuring agreements were signed in 1998, have been recapitalized by private shareholders and the government and the restructuring of their operations and management 
has begun. However, the situation of a third restructured bank remains precarious because the private shareholders have not yet supplied the additional capital. ${ }^{6}$ The government is continuing with the judicial proceedings to recover the bad loans of a bank which was closed in 1997; in the meantime, 96 percent of the deposits have been reimbursed with government funds. ${ }^{7}$ To strengthen bank supervision, the central bank has restructured and restaffed the bank inspection department in accordance with the recommendations of the Basel Committee on Banking Supervision. The central bank has also taken over the supervision of microfinance institutions, and the government has launched a request for bids for the operation of the largest microcredit institution. The sales of savings bonds by the central bank to the private sector were delayed to April 1999; thus far, however, but sales have been quite weak.

21. Other structural reforms were implemented as anticipated. The business arbitration court has begun operations. The restructuring plan for the social security fund (CNSS) was adopted by the government in November 1998, and the reorganization of its financial and accounting departments is under way.

\section{Report ON THE Discussions AND the 1999/2000 Program}

22. The discussions on a program to be supported by a third arrangement under the ESAF took place during four visits to Conakry in 1999-in January-February, in May, in September and in November. Understandings on a program were reached during the first visit, but, when it became clear that the original 1999 budget was not tenable, it was decided not to present the program to the Executive Board. In May, the authorities and the staff agreed that a consolidation period was necessary before presenting a revised program to the Board.

\section{A. Prior Actions to Program Discussions}

23. In May 1999, as a prelude to the eventual understanding on a program to be supported by a third annual ESAF arrangement, the staff insisted that the macroeconomic situation be stabilized and that some key structural actions be taken to ensure that the fiscal problems encountered at the end of 1998 and the beginning of 1999 would not be repeated. The key to macroeconomic stabilization was fiscal consolidation, in line with the 1999 budget adopted by the government in June. During May-August 1999, budgetary revenue increased by 8 percent compared with that in the first four months of the year (Box 2). This occurred despite a drop in the effective petroleum tax rate resulting from the increase in the world price of oil and the

\footnotetext{
${ }^{6}$ The bank that has to be recapitalized comprises about 5 percent of the banking system.

${ }^{7}$ Only about 6 percent of the outstanding credit of the bank at the time of closure has since been recuperated.
} 
exchange rate depreciation. ${ }^{8}$ Moreover, over the same period, the government squeezed expenditure by 7 percent. In making expenditure decisions, it followed a strict hierarchycivil service salaries and ECOMOG expenditures were paid first, followed by expenditures to priority social sectors (health, education, social affairs, and transport infrastructure), and, finally, nonpriority ministries. A civil service wage increase, which had been slated for July 1, 1999, was postponed to October 1, 1999. The result of the renewed fiscal discipline was a marked increase in the primary surplus and a positive domestic balance. Net banking system credit to the government during 1999 was reduced from its peak of GF 70 billion (17 percent of beginning-of-period money) in July to GF 39 billion ( 9.5 percent). The money supply dropped in nominal terms and the net foreign assets of the central bank increased.

\begin{tabular}{|c|c|c|c|}
\hline \multicolumn{4}{|c|}{ Box 2. Guinea: Central Government Operations, 1999} \\
\hline & $\begin{array}{c}\text { Jan.-April } \\
\text { Actual }\end{array}$ & $\begin{array}{c}\text { May-Aug. } \\
\text { Actual }\end{array}$ & $\begin{array}{c}\text { Sep.-Dec. } \\
\text { Program }\end{array}$ \\
\hline & \multicolumn{3}{|c|}{ (In billions of Guinean francs) } \\
\hline Revenue & 164 & 177 & 185 \\
\hline Domestic expenditure & 167 & 153 & 154 \\
\hline $\begin{array}{l}\text { Cuirrent } \\
\text { Of which }\end{array}$ & 154 & 133 & 141 \\
\hline Interest obligations & 25 & 19 & 28 \\
\hline Domestically financed investment & 14 & 21 & 12 \\
\hline Primary balance & 21 & 43 & 59 \\
\hline \multirow[t]{2}{*}{ Overall domestic balance $1 /$} & -4 & 24 & 31 \\
\hline & \multicolumn{3}{|c|}{ (In percent of GDP) } \\
\hline Revenue & 3.3 & 3.5 & 3.6 \\
\hline Domestic expenditure & 3.3 & 3.1 & 3.0 \\
\hline Primary balance & 0.4 & 0.8 & 1.2 \\
\hline Overall domestic balance & 0.0 & 0.4 & 0.6 \\
\hline
\end{tabular}

Sources: Guinean authorities; and staff estimates and projections.

1/ Revenue minus domestic expenditure.

${ }^{8}$ The petroleum price is fixed and, tax revenue is an after-cost residual. The government increased the price of petroleum products on October 6, 1999 by $15-20$ percent to ensure continued revenue in the last quarter of 1999 and 2000 . The government is considering moving to a flexible pricing system in 2000 . 
24. Structural measures taken by the authorities as prior actions to Executive Board consideration of the program are spelled out in Box 3. Among the most important measures taken were those to reinforce expenditure management and begin replacing the computerized expenditure management system for the year $2000{ }^{9}$ Another series of measures was aimed at beginning the process of customs reform. In addition, a foreign exchange auction at the central bank was established, with a view toward unifying the exchange rate. The auction began operation on September 1, 1999. (Box 1). Finally, in light of the tax fraud at the alumina parastatal, the staff team urged the authorities to undertake audits of some other key parastatals, including ANAIM, the National Agency for the Development of Mining Infrastructure (Box 3).

\section{B. The 1999/2000 Economic Program}

25. Based on the improvement in the macroeconomic situation in the second part of 1999 and the structural measures that had been taken, understandings were reached in September on a program for the period October 1, 1999 to September 30, 2000. However, revenue mobilization in September and October was weaker than expected, as a result of a shortfall in customs revenue, stemming from lower imports and continued weak customs administration. The November mission focused on expenditure cuts that could be taken to ensure that the primary balance target was met and on further measures to reinforce customs administration. The program objectives for 1999 were revised, while those for 2000 were left largely unchanged.

\section{Growth and inflation}

26. Consistent with the medium-term framework, the program to be supported by the third annual ESAF arrangement envisages real GDP growth increasing from 3.7 percent in 1999 to 5 percent in 2000 (Tables 1 and 2). In the primary sector, investment in a new fishing port, vocational training for fishermen, and efforts to deepen the domestic market are expected to allow rapid growth in fishing. Output in the secondary sector is expected to increase by almost 7 percent, with several foreign partners expected to make a substantial investment in both physical and human capital in several large alumina and bauxite state companies. Also, the opening of the Garafiri Dam in 1999 will allow the electrical grid to be extended. Trade and transport should pick up somewhat from their sluggish performance in 1999. Inflation is expected to moderate during 2000, reaching about 4 percent by end-December. ${ }^{10}$ Investment would increase from 18.2 percent of GDP in 1999 to 19.2 percent in 2000 , reflecting a rise in private mining activity and continued growth in the public investment program. This increase would be supported by growth in domestic savings over the same period from 17.4 percent of GDP to 18.2 percent (Table 3 ).

${ }^{9}$ The computerized expenditure system was finally made functional in the second quarter of 1999 , but as it is not Y2K compliant, it must be replaced.

${ }^{10}$ Average inflation for 2000 is projected to be 5.8 percent, reflecting the 1999 petroleum price increase and the rapid exchange rate depreciation late in 1999 (see below). 
Box 3. Structural Measures Implemented, April-October 1999

\section{Measures}

Certification of social security accounts at end-1998.

Nomination of customs reform committee.

Strengthening of financial control department by implementing procedures to control allocation of budget envelopes.

Prohibition of manual expenditure commitments, overruns of budget envelopes, and payments of noncommitted expenditure.

Draft of revised budgetary nomenclature for comment by IMF staff.

Adoption of a revised budget by government, including postponement of civil service wage increase from July to September.

Request for bids for new preshipment inspection (PSI) company.

Request for bids for equipment for new computerized expenditure-monitoring system.

Completion of audit of mining infrastructure company (ANATM).

Introduction of foreign exchange auction.

Increase in retail price of petroleum products.

Decision on choice of new import verification company.

Request for bids and decision on firms to audit four key parastatals for possible tax fraud (port, electricity, telephone, and water).

Request for bids for audits of customs tax invoices and customs operations at airport.

Creation of a debt department separate from the budget department and definition of specifications for new debtmonitoring software.

Updating of social security contributor files.

\section{Date Completed}

April 1999

June 1999

June 1999

June 1999

June 1999

July 1999

July 1999

August 1999

August 1999

September 1999

October 1999

October 1999

October 1999

October 1999

October 1999

Ongoing 


\section{Fiscal policy}

27. Fiscal policy under the program is aimed at strengthening the public finances through increasing revenue (particularly from customs) and reinforcing expenditure control. The 2000 budget calls for a primary surplus of 2.7 percent of GDP, compared with 2.4 percent in the final 1999 budget plan (Table 4). Revenue is expected to rise by 21 percent, from 10.4 percent of GDP in 1999 to 11.5 percent of GDP in 2000 . Most of the increase will come from customs revenues, based on a fundamental reform of customs operations, with the help of Fund technical assistance (see Box 4 and Table 3 of the Memorandum of Economic and Financial Policies).

28. Guinea has an almost uniform import tariff rate of 17 percent, with higher rates for some food products and lower rates for other selected products, bringing the unweighted average tariff rate down to 16.4 percent. Export taxes apply to diamonds ( 3 percent), gold and other precious metals ( 3 percent), and selected other products ( 2 percent). There are no substantial nontariff barriers. ${ }^{11}$ In the near future, possibly as soon as January 1,2000 , the authorities plan to bring Guinea's tariff regime in line with that of the neighboring customs union, the West African Economic and Monetary Union, so as to facilitate regional integration and reduce smuggling. ${ }^{12}$ The authorities are now calculating the fiscal consequences of such a change.

29. Domestic primary expenditure in the 2000 budget will rise from 8 percent of GDP in 1999 to 8.8 percent in 2000 . The 2000 budget includes a precautionary full year of funding for ECOMOG forces in Sierra Leone ( 0.4 percent of GDP), allocations for general and local elections that had originally been scheduled for 1999 , and a 17 percent increase in the nonwage operating expenditure in priority social sectors, bringing it to 5.1 percent of GDP. The total wage bill will rise by 4.2 percent, reflecting (a) the full-year impact of 1999 army promotions; (b) the 1999 civil service wage increase; and (c) new recruitment in education.

30. The overall budgetary deficit-on a commitment basis, excluding grants-is projected to widen from 4.8 percent in 1999 to 5.3 percent of GDP in 2000; if grants are included the deficit widens from 3.0 percent of GDP in 1999 to 3.2 percent in 2000 . After taking account of scheduled debt service on domestic and external debt and repayment to the central bank of GF 24 billion (of the GF 42 billion borrowed in 1999), the total financing required amounts to the equivalent of US\$118 million, which could be provided by multilateral and bilateral donors and through an extension of the existing Paris Club rescheduling.

"Guinea has a rating of 3 on the Fund's index for trade restrictiveness which covers both tariff and nontariff barriers.

${ }^{12}$ The common external tariff of the WAEMU consists of four tariff bands, with rates of 0,5 , 10 , and 20 percent. 


\section{Box 4. Customs Reform}

Customs revenue represents a large part of budgetary revenue in Guinea (52 percent on average during 1995-98). In 1996, in an effort to increase revenue from duties and taxes on imports, the government hired a private preshipment inspection (PSI) company (the Société Générale de Surveillance-SGS), giving it a three-year contract to improve revenue performance and to provide training and technical assistance to the Customs Directorate. The SGS was given responsibility for the clearance of shipments with a f.o.b. value of US $\$ 3,000$ or more, while the Customs Directorate retained responsibility for goods below that value, as well as for nonmaritime shipments, goods exempt from duties and taxes, and inland border and passenger traffic.

Performance of border tax collections did not improve much after the hiring of the SGS (the revenue increase in real terms was moderately positive in 1997 and negative in 1998), and the provision of technical assistance and training services has been minimal (in part because of the lack of interaction between the SGS and the Customs Directorate). Moreover, as the share of exempted imports in the total rose from 44 percent in 1997 to 46 percent in 1998, the revenue forgone, owing to exemptions, rose from the equivalent of 53 percent of revenue from import taxes to 61 percent.

The problems affecting this weak revenue performance include poor control and monitoring of exemptions; inadequate control procedures (systematic verification of goods but no record of penalties); and inadequate facilities at major offices. In addition, the Customs Directorate must deal with important issues before it can resume its former responsibilities: poor allocation and lax supervision of staff (contributing to problems of comuption), insufficient technical training, and the absence of a work plan to modernize its procedures.

To redress this situation, a customs reform plan was put together, following a technical assistance mission from the Fund in early 1999. It includes three major components: (a) a redefinition of the role of the PSI company the services of which are to be retained during an interim period; (b) an improvement in import taxation and a reduction in exemptions; and (c) an ambitious program to modernize the Customs Directorate and its procedures. The SGS's contract that was to have expired by August 1999 has been extended to end-1999, with the conditions of its cooperation with the Customs Directorate clearly spelled out. A new PSI tender was launched in August 1999, for a contract to start on January 1, 2000 and focusing on a clearly defined role for the PSI, particularly the transmission of know-how in working procedures and training to customs staff.

To improve import taxation and reduce exemptions, the customs reform includes actions to strengthen monitoring and control of exemptions; effective control over imported goods in customs areas; establishment of a database for import values; and development of an action plan to combat fraud and smuggling. In addition to increased training, the Customs Directorate's efficiency will be reinforced through the simplification of procedures; a reduction of the workforce; the establishment of a code of conduct; tight supervision of staff and prosecution of corrupt officers; a closer cooperation between the PSI company and the Customs Directorate; the intensive use of computer technology; and improved working conditions. In response to lagging customs revenues in September and October 1999, the government took several severe measures to tighten controls immediately. Most importantly, they prohibited the use of any emergency customs clearance procedures, required that all oil imports pay duties with exempted imports receiving refunds, and reinforced control of exemptions under the mining and investment codes. 


\section{Monetary policy}

31. The program envisages M2 growth of 9.5 percent in 1999 and 10.0 percent in 2000 (Table 6). Monetary policy in Guinea is strongly influenced by fiscal policy. In this context, and given the budgeted repayment of government credit to the banking system at the end of 1999 and in 2000, monetary policy will aim at rebuilding central bank reserves and providing sufficient credit to the private sector to sustain real growth. The net foreign assets of the central bank are programmed to increase from their September 1999 low of US $\$ 75.4$ million to US $\$ 110$ million by end $-2000,{ }^{13}$ corresponding to gross reserves of 3.2 months of imports at end-2000. Reserve accumulation by the central bank should become easier as the rigidities in the foreign exchange market lessen with the progressive unification of the exchange rate (Box 1). Private sector credit is slated to expand by 14 percent in 1999 (an expansion that began in August) and by 9 percent in 2000 .

32. During the November discussions, the staff underscored the importance of letting the exchange rate float and of not interfering in the foreign exchange auction. ${ }^{14}$ They also noted that an increase in interest rates could help to slow the depreciation of the Guinean franc. The authorities expressed their commitment to allow a pure float, except to meet net foreign asset targets, and to mobilize foreign exchange earnings of state enterprises to deepen the foreign exchange auction. They also raised the minimum term-deposit rate from 6 to 8 percent.

33. The Central Bank of the Republic of Guinea (BCRG) will continue to improve banking supervision and strengthen the banking system. Reform will begin with the central bank itself. Fund technical assistance found severe deficiencies in its internal audit procedures. While the BCRG has taken steps to address these problems, it was decided that it would be prudent to have an external audit of central bank accounts, which will begin by March 2000. For commercial banks, closer surveillance of prudential and reserve requirements will be undertaken by the bank supervision department, with monthly reports filed on the situation of each bank. The BCRG will begin harmonizing the special tax agreements (conventions d'établissement) of the commercial banks to ensure banks compete on the same footing. As a first step toward bringing the banking laws and regulations into compliance with the 25 principles of the Basel Committee, the central bank will prepare a memorandum on the changes that need to be made and a timetable for effecting them. The government will continue the restructuring of the microcredit institutions with an audit and full recapitalization

${ }^{13}$ At end-December 1998 central bank net foreign assets were about US\$113.6 million. However, that level was abnormally high owing to year-end donor disbursements. End-November 1998 reserves were only US\$72.1 million.

${ }^{14}$ This was in response to the authorities having changed the modalities of the auction in early November (see Box 1). 
of one of such institutions, the development of a new set of supervisory regulations, and the reinforcement of central bank supervision. The chart of accounts for the banking system will not be operational on January 1,2000 as expected, because resources have had to be diverted to resolving Y2K problems at the central bank and in the commercial banks. Thus, it will become operational in 2001, because the same chart must be used for an entire fiscal year.

\section{External sector and medium-term outlook}

34. The current account deficit is expected to widen to 6.3 percent of GDP in 2000 reflecting a widening deficit on services and income. That deficit, in turn, is related to a continued increase in public investment and to the restructuring of companies in the alumina/bauxite sector, which require an increase in imports financed by foreign direct investment inflows. The impact of this one-off investment will be felt only in 2000 , and in 2001 the current account deficit is projected to narrow again to 5.3 percent of GDP.

35. Capital inflows in $\mathbf{2 0 0 0}$ are projected to recover, with a modest growth in project loans after their rapid expansion in 1999. Amortization due on public debt will decline somewhat in 2000, and substantial debt relief expected from the Paris Club and other creditors will significantly reduce actual payments. Private investment flows are expected almost to double (see above). The overall balance of payments deficit is projected to decline from 3.2 percent of GDP in 1999 to 2.4 percent in 2000 and 1.6 percent in 2001.

36. Guinea has benefited from US\$23.9 million in debt relief from Paris Club creditors in 1999 and is projected to receive a further relief of US $\$ 20.8$ million in $2000 .{ }^{15}$ However, Guinea's total financing requirements continue to be dominated by the need to clear outstanding arrears with Russia and non-Paris Club creditors, amounting to some US\$475 million. Taking account of nonreschedulable arrears and 1999 debt-service payments, a total of US $\$ 508$ million needs to be rescheduled.

37. Guinea's medium-term balance of payments outlook will be affected by the developments in the mining sector and the public investment program (PIP). The merchandise trade balance is projected to continue to improve on the basis of an expansion in mining production and a recovery in bauxite, alumina, and gold prices. Imports are driven by intermediate goods required for the implementation of the PIP and investment in the mining sector; the volume of imports of food and petroleum products will grow more modestly as domestic agricultural and hydroelectric production pick up. With growing merchandise exports, the current account deficit, excluding public transfers, is expected to fall from 6.3 percent of GDP in 2000 to 5.3 percent in 2001. During the period 2000-01, overall financing requirements are projected to average US $\$ 210$ million per year, about one-half of

${ }^{15}$ This assumes extension of existing Naples terms. Resources freed by any more concessional treatment would likely be used for priority social sector outlays. 
which should be covered by official transfers, concessional loans, and net foreign direct investment. The financing gap is estimated at US\$112.6 million in 2000 and US\$98.1 million in 2001 , with debt relief covering about a one third of the total.

\section{Structural reforms, governance, and social issues}

\section{The program's structural reforms are focused on budgetary and treasury} operations, customs and the banking system, as mentioned above (see also Tables 2 and 3 of the Memorandum of Economic and Financial Policies attached to Appendix I). In addition, there is an ongoing program of public enterprise reform. With the assistance of the World Bank, the government has reviewed the 63 existing public enterprises to assess their viability. By June 30,2000 , the government will liquidate 12 enterprises that have ceased activities and will reduce government participation in 7 enterprises in which it has a minority holding and which remain viable. For the others, it will work out an action plan that best responds to the need for divestiture, while safeguarding the public interest. These new activities supplement ongoing efforts to privatize and restructure the mining companies and increase private sector participation in public utilities. A detailed privatization plan will be an integral part of the next World Bank lending operation in 2000.

\section{The reform of the social security fund (CNSS) will continue. Before} recapitalization can begin, several actions need to be taken. First, the reorganization of the financial and accounting departments begun in 1999 must be completed. Second, the file of contributors must be updated, including a determination of outstanding amounts due. This updating will be accompanied by a plan to collect overdue receipts. Third, an actuarial study will be undertaken to establish the level of recapitalization needed to ensure the medium-term viability of the fund. Fourth, yearly audited accounts will be produced by independent auditors. A part of the pay raise granted to civil servants in October was to be withheld for social security contributions. The union threatened to strike and the government rescinded the withholding. However, in the November discussions, the authorities affirmed their intention to reinstitute withholding as soon as budgetary and social conditions permit.

40. Governance issues remain an important concern in Guinea. The actions taken by the authorities in this regard to date are summarized in Box 5. For the coming year, besides the audit of the central bank, the authorities will establish an anticorruption commission and, with the help of the World Bank, will put together a far-reaching medium-term anticorruption strategy. Also, a plan to reform ANAIM, in light of the audit conducted, will be developed. In addition, judiciary reform will continue with legislative reform and the reorganization of prison administration (Appendix II, Attachment, paragraph 29). 


\section{Box 5. Governance Issues}

Private economic operators, unionists, nongovernmental organizations (NGOs), donors and foreign embassies all cite corruption-both inside and outside the government-as a pervasive problem in Guinea, arguing that a culture of corruption severely hinders the development of legitimate economic activity. The government acknowledges the problem, but to date corruption issues have been treated in a case-by-case manner. In 1999, after several highly visible cases of fraud, the authorities decided to develop a coherent strategy to fight corruption.

Fraud cases in 1999. Two important cases of fraud were uncovered late in 1998 and 1999. The first involved Friguia, the alumina parastatal. Late in 1998, the Minister of Mines requested an audit of unusually large tax payments made by Friguia in 1997. The audit uncovered payments from Friguia of 1996 taxes that had been forgiven. Although the copies of the checks in Friguia's records showed payment to the tax authorities, no payments had been received by the treasury. Tracing of the checks found that they had been deposited with screen companies in Conakry. The Finance Director of Friguia and the Director of Taxes were removed from their positions early in 1999, and Friguia filed a complaint against them, among others, in the second quarter in 1999. After a prolonged internal investigation of countercharges against other government officials, the government joined in Friguia's complaint and three of the accused were arrested in late September. They are now awaiting trial. Continued audits of Friguia accounts showed problems with payments of customs duties as well, which are being followed up.

The second case involved ANAIM, the parastatal mining research and development company. An audit was extended to look at the end-1998 accounts. The outside auditor found substantial irregularities in the accounts, including diversion of customs duties. The accused were promptly arrested and are awaiting trial. The government has tightened controls on ANAIM's financial operations and, as part of the program, has agreed to make proposals for cleaning up and transforming ANAIM.

Short-term actions. As a prior condition to negotiation of the program, the government agreed to begin audits of the four major parastatal companies (electricity, water, telephone, and the Port of Conakry) to see if fraud similar to that of Friguia or ANAIM had taken place. After securing World Bank financing for these audits, the request for bids was published in August and the audits began in October. The results are expected in early 2000 . In addition the government agreed to conduct audits of customs operations at the airport and of the procedures used by customs to issue preliminary and final tax invoices (bordereaux de taxation). The request for bids for these audits was launched in October. Finally, as a follow-up to Fund technical assistance on internal audit procedures, the central bank has agreed to an external audit of its accounts as of end-1998, which should begin in the second quarter of 2000 .

Medium-term plan. The government has come to the conclusion that a more systematic approach must be taken to combating corruption, particularly fraud and misuse of government funds. To this end, President Conté requested technical and financial assistance from the World Bank to put together an anticomuption strategy. The first step will be the creation of an anticomuption commission by endDecember 1999, representing all sectors of the Guinean establishment (e.g., the executive and judiciary branches, unions, businessmen, and NGOs). Donors have indicated a willingness to finance an audit fund. The anticorruption strategy to be developed by the commission and the government will be a key component of the 2000 World Bank lending operation. 
41. Social indicators are very weak in Guinea, despite per capita income above the sub-Saharan average (Table 8). As indicated in Appendix II, the authorities have initiated a wide range of programs to combat poverty; chief among them is the increased budgetary resources given to the key priority social sectors of health, education, justice, social affairs, and infrastructure. Accompanying the provision of these resources is an enhanced framework for planning, ensuring delivery, and evaluating results on the basis of predetermined performance indicators. The mission discussed with the authorities the need to develop a poverty reduction strategy (PRS) in the context of the enhanced HIPC Initiative and future ESAF/PRGF lending. The authorities indicated that much of the groundwork had been done and that they were prepared to develop a PRS in the coming months, but no specific schedule has yet been adopted. The Fund and World Bank teams are planning a joint visit to Conakry in the first quarter of 2000 to launch the PRSP process.

42. Sectoral policy issues are reviewed in detail in the policy framework paper (EBD/99/134). Reforms are focused on poverty alleviation, decentralization of services, and reinforcement of the private sector.

\section{Year 2000}

43. Guinea is reasonably well prepared to confront the Y2K problem. Government Y2K efforts are coordinated by an interministerial committee. A thorough inventory of problems in the financial sector was done in 1998-99 and corrective measures have been taken; all banks and insurance companies have been certified as being $\mathrm{Y} 2 \mathrm{~K}$ compatible. Backup measures and contingency plans are also in place. Similarly, most government agencies appear now to have taken corrective or preventive measures. One remaining point of vulnerability is the telephone system, where progress is not as advanced as hoped.

\section{Program monitoring}

44. Performance criteria and structural benchmarks are listed in Tables 1 and 2 of the MEFP attached to Appendix I. Progress under the program will be assessed in the context of two reviews, the first of which is to be completed not later than June 30,2000 and the second to be completed not later than December 31, 2000.

\section{STAFF APPRAISAL}

45. Toward the end of 1998, the Guinean authorities confronted a number of serious shocks that were beyond their control: a drop in mining revenues, rapidly increasing financial commitments to regional peacekeeping forces, and expenses associated with defending the country's borders and hosting a refugee community of between 5 and 10 percent of its 
population. These problems were aggravated by a drop-off in commercial activities related to the presidential elections. In an attempt to meet end-1998 spending targets, the government postponed the expenditure payments into 1999, in the hope that the difficult conjunction of economic and security problems would soon be resolved.

46. Unfortunately, attempts to bring peace to Sierra Leone early in 1999 failed, commodity prices did not rebound, and the hesitancy of economic operators persisted. Thus, in 1999 the authorities found themselves with an expenditure overhang, sluggish revenue collections, and no immediate prospects of external budgetary support. Government borrowing from the banking system ballooned, expanding the money supply and putting the price stability that had been established over the last several years in jeopardy. These problems were exacerbated by weak institutional procedures and controls. On the monetary side, the persistence of a gap between the official exchange rate and the parallel rate accelerated the drawdown of the central bank's reserves.

47. By end-April 1999, it was evident that the situation was untenable and that the authorities had to face up to their economic management problems or risk serious macroeconomic destabilization. In consultation with Fund staff, the government revised its budget and adopted fiscal and monetary targets aimed at stopping monetary expansion by scaling back and controlling expenditure to meet revenue. End-August figures showed a marked reversal of the situation. Such action in a relatively short period of time is laudable, especially given the budgetary dilemmas faced by the authorities. While defense and ECOMOG expenditures were deemed essential, the authorities recognized the importance of meeting their commitments to key development sectors (health, education, social affairs, and infrastructure). Furthermore, they paid about US\$60 million of debt service (1.6 percent of GDP) in the first nine months of 1999 with no external budgetary assistance.

48. The program for 1999-2000 will continue to pose difficult problems of financial management. While monetary and financial targets for end-1999 are achievable, it will take strong actions to meet 2000 targets. For 2000 , the budget, which for the first time in several years has been approved by the government before the fiscal year begins, includes the continuation of spending at the current pace. Although such spending could be scaled back if the regional security situation improves, it is better not to count on such improvement, as did the original 1999 budget. Allocations for social sectors have been increased. Repayment of government debt to the central bank should clear the way for increased private sector credit and the rebuilding of foreign exchange reserves. The key to being able to meet expenditure goals will be revenue mobilization, especially at customs. Customs reform is likely to be unpopular, but it is essential to widening the tax base and ensuring revenue performance.

49. Exchange rate policy must be more clearly defined. The authorities should allow the Guinean franc to float freely subject to attaining the program's target for net foreign assets. To speed unification of the exchange rate, the foreign exchange auction should be deepened, particularly by ensuring parastatal foreign exchange is sold there. These actions need to be reinforced by higher interest rates than prevailed in 1999. 
50. The program's structural measures are focused on continuing to strengthen financial and economic management tools. The new computerized expenditure system, to be in place at the beginning of 2000, will be essential for effective control of expenditures, while the monthly production of treasury balances will ensure a tighter link between fiscal and monetary policy. An audit of the central bank, accompanied by reinforced bank supervision and a reworking of the underlying banking legislation and regulations, will provide a firmer footing for the banking sector. In consultation with the World Bank, privatization efforts will continue, marked by the liquidation of 12 enterprises by end-June 2000 . The establishment of a comprehensive plan to end the government's involvement in commercial activities is essential.

51. Governance issues remain an important concern in Guinea, but the government appears to be confronting some aspects of it head-on. The establishment of an anticorruption commission is a visible step forward, but the government must ensure that the commission functions openly and forcefully. In parallel, economic security needs to be improved; in this regard the justice system, which needs to be strengthened, must not be fettered.

52. It is disturbing to note that, while Guinea's per capita income is above that of sub-Saharan Africa, its social indicators are almost uniformly worse. The enhanced HIPC Initiative could provide important debt relief to Guinea that will allow the government to concentrate on the fight against poverty. Development of a comprehensive poverty reduction strategy formulated through a broad-based and transparent participatory process will be an important step forward.

53. The economic program for $1999 / 2000$ is not without risks. In particular, expenditure pressures will continue, and the authorities will need to be vigilant in mobilizing revenues. They will also need to calibrate expenditure to revenue and ensure proper budgetary procedures are followed. Unification of the foreign exchange market will remain a politically sensitive issue, but it must be pursued if the cartelization of the banking system is to be broken, and the exchange rates must be allowed to float.

54. On the basis of the actions taken since May to reestablish budgetary equilibrium, tighten monetary and financial controls, and strengthen monitoring and control procedures, the staff recommends approval of the extension of the ESAF commitment to January 12, 2001 and the government's requests for the third annual arrangement under the ESAF.

55. It is recommended that the next Article IV consultation be held on the usual 12-month cycle. 


\section{PRoposed Decision}

The following draft decision is proposed for adoption by the Executive Board:

1. The government of Guinea has requested: (i) the extension of the commitment period of the three-year arrangement for Guinea under the Enhanced Structural Adjustment Facility (ESAF) (EBS/96/204; 12/27/96) to January 12, 2001; and (ii) the third annual arrangement under the ESAF in an amount equivalent to SDR 23.6 million.

2. The Fund has appraised the progress of Guinea in implementing economic policies and achieving its objectives under the program supported by the second annual arrangement, and notes the updated policy framework paper for Guinea set forth in EBD/99/134.

3. The Fund approves: (i) the requested extension of the commitment period; and (ii) the third annual arrangement set forth in EBS/99/221. 
Figure 1. Guinea: Official and Parallel Exchange Rates, January 1998-October 1999
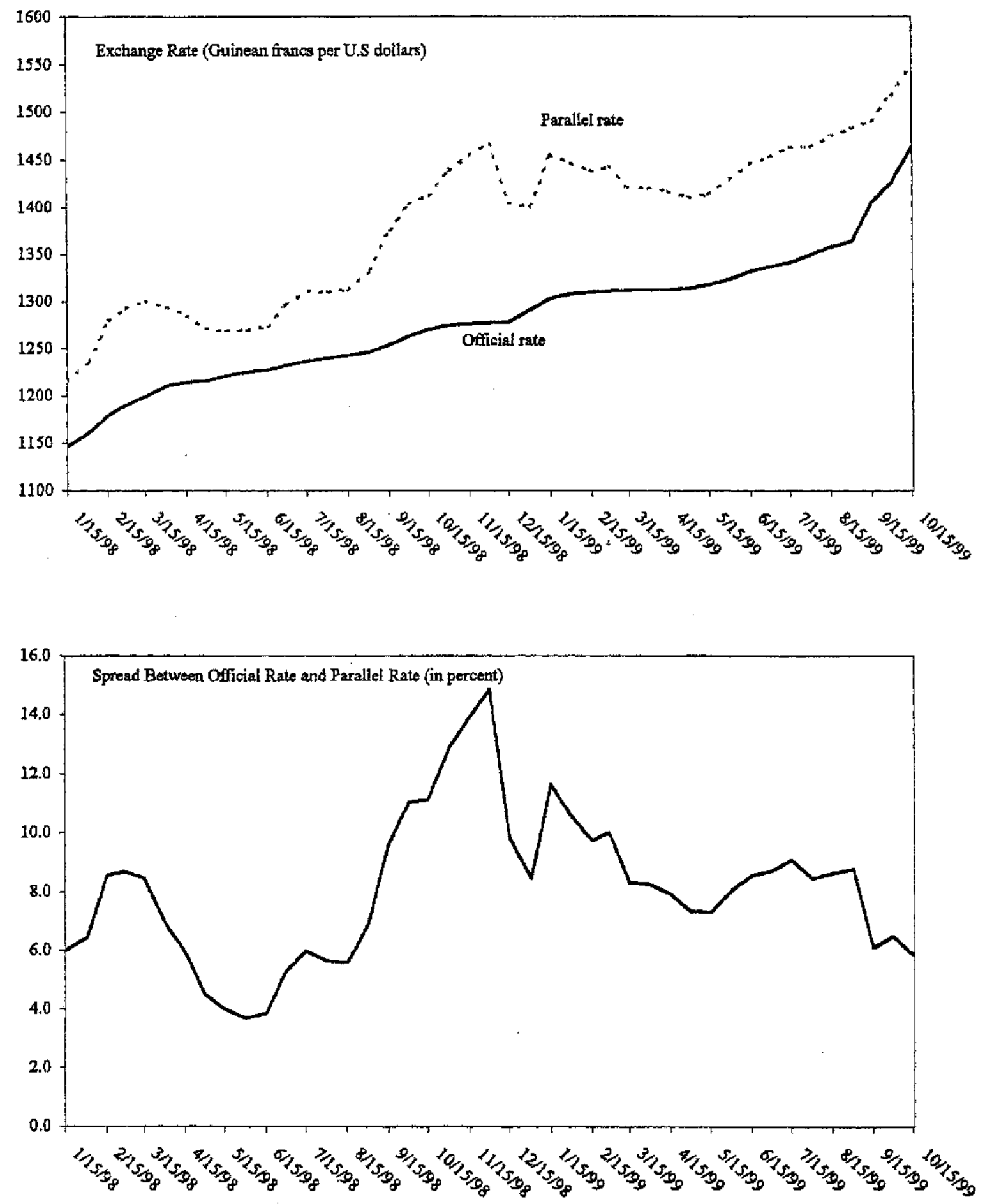

Source: Guinean authorities. 
Figure 2. Guinea: Effective Exchange Rates, January 1992-August 1999

(Index 1990 = 100)

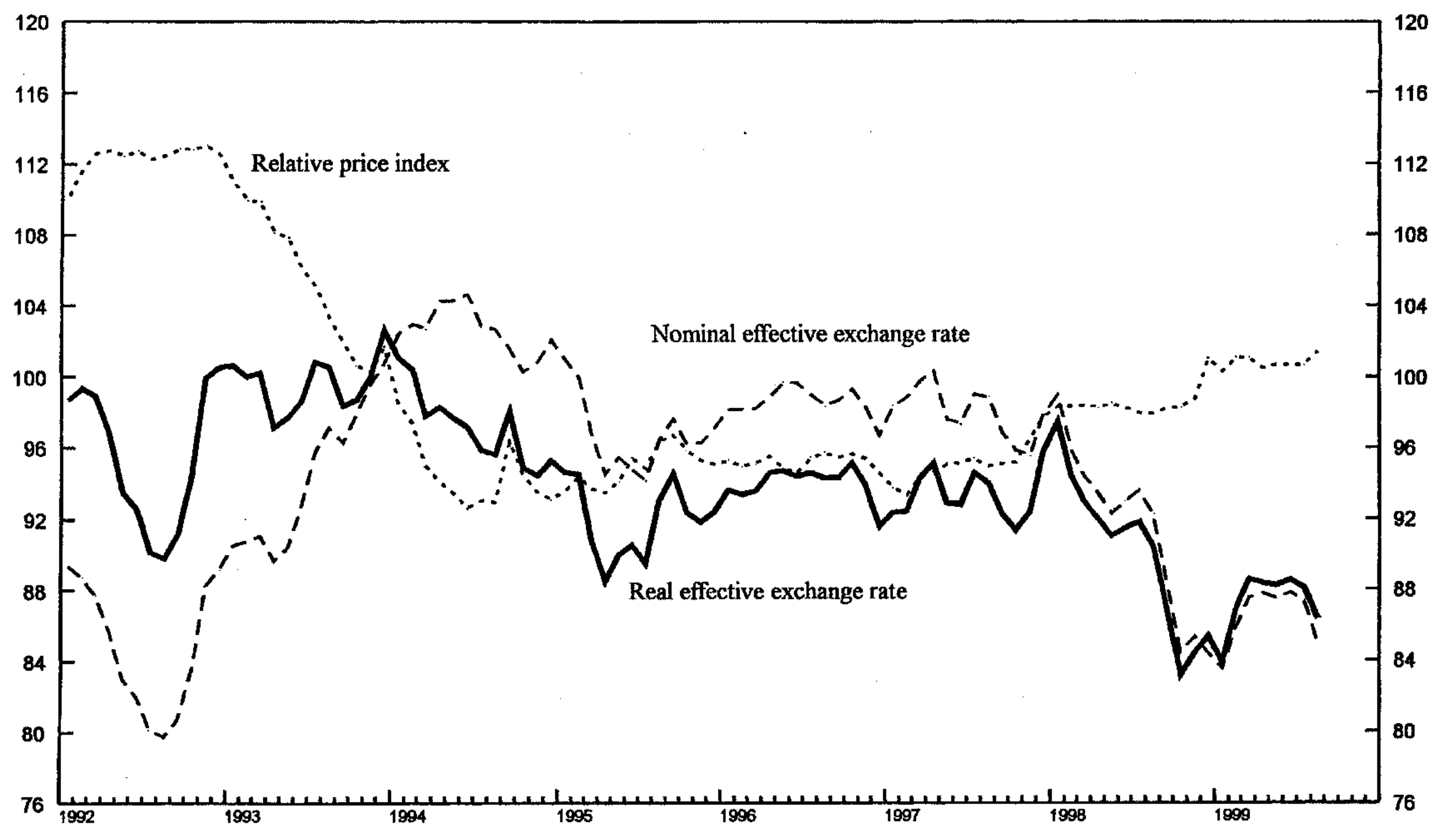

Source: IMF, Information Notice System (INS). 
Table 1. Guinea: Selected Economic and Financial Indicators, 1997-2001

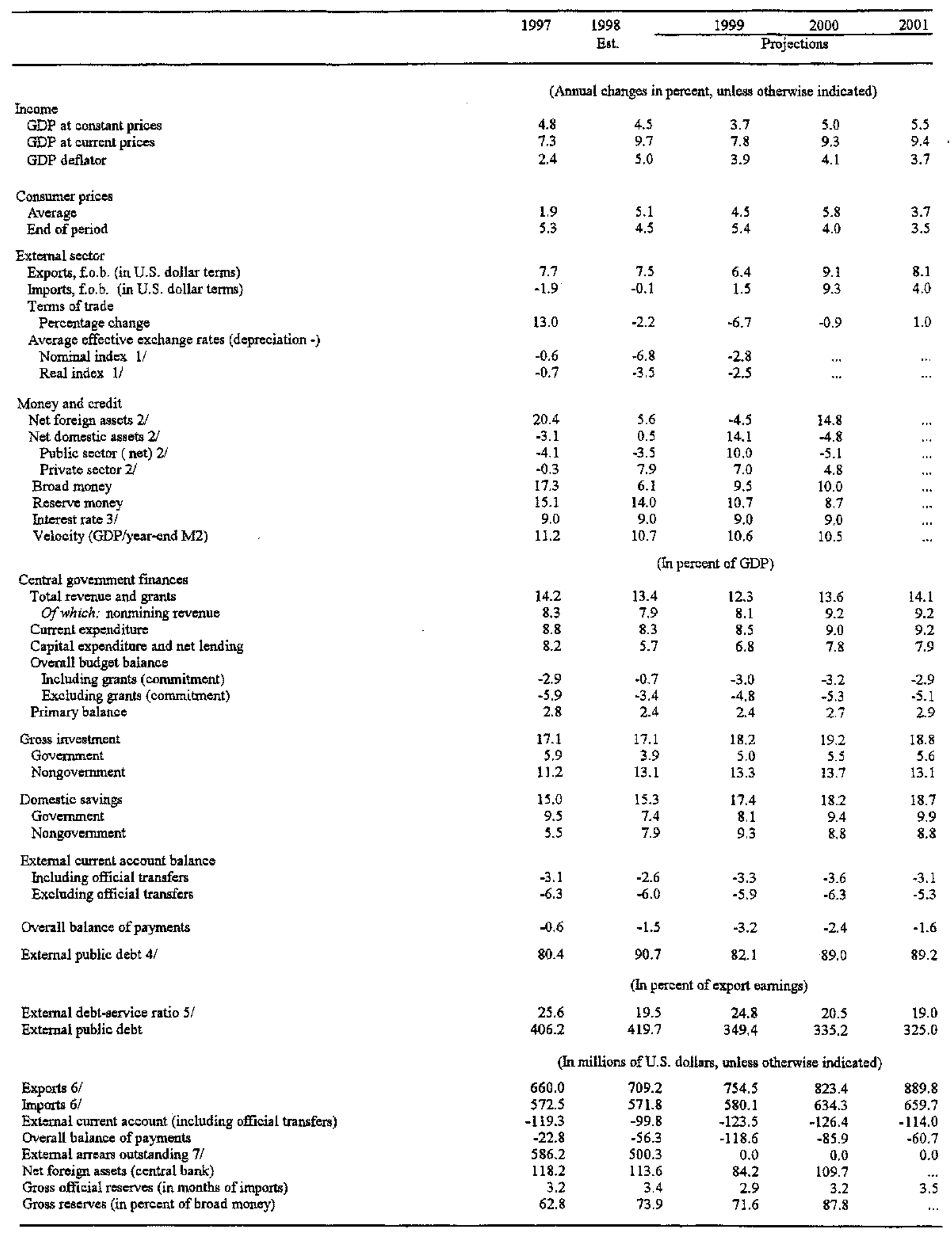

Sources: Guinean authorities; and staff estimates and projections.

1/ For 1999, figures show change for the first six months of the year only.

$2 /$ In percent of broad money stock at beginning of period.

3/Minimum annual rate on bank savings deposits, at end of period.

4/ Including debt owed to the Fund and to the former Soviet Union.

5/ Scheduled public debt service, including IMF charges and repurchases.

6/ Merchandise trade figures only.

7/ End-of-period figures, assuming all rescheduling takes place in 1999. 


$$
-29=
$$

Table 2. Guinea: Gross Domestic Product at Constant 1994 Prices by Sectors, 1997-2001

\begin{tabular}{|c|c|c|c|c|c|}
\hline & 1997 & 1998 & 1999 & 2000 & 2001 \\
\hline & \multicolumn{5}{|c|}{ (In billions of 1994 Guinean francs) } \\
\hline GDP at factor cost & $3,691.44$ & $3,862.96$ & $4,005.02$ & $4,203.50$ & $4,429.70$ \\
\hline Primary sector & 784.31 & 824.75 & 861.48 & 906.10 & 956.40 \\
\hline Agriculture & 538.23 & 565.15 & 590.58 & 620.11 & 654.21 \\
\hline Livestock & 126.60 & 133.82 & 140.95 & 148.70 & 157.18 \\
\hline Fisheries & 36.98 & 41.05 & 43.10 & 48.27 & 53.59 \\
\hline Forestry & 82.50 & 84.73 & 86.85 & 89.02 & 91.42 \\
\hline Secondary sector & $1,102.09$ & $1,155.55$ & $1,230.01$ & $1,313.14$ & $1,408.41$ \\
\hline Mining & 608.37 & 630.27 & 679.43 & 731.07 & 788.82 \\
\hline Manufacturing & 146.26 & 153.87 & 162.33 & 169.47 & 178.79 \\
\hline Water, electricity & 19.21 & 20.84 & 21.90 & 25.19 & 26.27 \\
\hline Construction & 328.25 & 350.57 & 366.35 & 387.41 & 414.53 \\
\hline Tertiary sector & $1,805.04$ & $1,882.66$ & $1,913.53$ & $1,984.26$ & $2,064.89$ \\
\hline Trade & $1,065.61$ & $1,116.76$ & $1,132.40$ & $1,175.43$ & $1,222.44$ \\
\hline Transport & 226.64 & 243.63 & 247.29 & 256.93 & 269.01 \\
\hline Administration & 175.85 & 166.13 & 174.49 & 182.85 & 187.04 \\
\hline Other & 336.94 & 356.14 & 359.35 & 369.05 & 386.40 \\
\hline Indirect taxes & 149.10 & 149.55 & 157.78 & 169.14 & 185.20 \\
\hline \multirow[t]{2}{*}{ GDP at market prices } & $3,840.54$ & $4,012.51$ & $4,162.80$ & $4,372.64$ & $4,614.90$ \\
\hline & \multicolumn{5}{|c|}{ (Annual percent change) } \\
\hline GDP at factor cost & 4.2 & 4.6 & 3.7 & 5.0 & 5.4 \\
\hline Primary sector & 5.1 & 5.2 & 4.5 & 5.2 & 5.6 \\
\hline Agriculture & 5.1 & 5.0 & 4.5 & 5.0 & 5.5 \\
\hline Livestock & 5.5 & 5.7 & 5.3 & 5.5 & 5.7 \\
\hline Fisheries & 10.0 & 11.0 & 5.0 & 12.0 & 11.0 \\
\hline Forestry & 2.5 & 2.7 & 2.5 & 2.5 & 2.7 \\
\hline Secondary sector & 4.4 & 4.9 & 6.4 & 6.8 & 7.3 \\
\hline Mining & 3.3 & 3.6 & 7.8 & 7.6 & 7.9 \\
\hline Manufacturing & 4.5 & 5.2 & 5.5 & 4.4 & 5.5 \\
\hline Water, electricity & 6.3 & 8.5 & 5.1 & 15.0 & 4.3 \\
\hline Construction & 6.2 & 6.8 & 4.5 & 5.7 & 7.0 \\
\hline Tertiary sector & 3.8 & 4.3 & 1.6 & 3.7 & 4.1 \\
\hline Trade & 5.1 & 4.8 & 1.4 & 3.8 & 4.0 \\
\hline Transport & 4.8 & 7.5 & 1.5 & 3.9 & 4.7 \\
\hline Administration & -6.3 & -5.5 & 5.0 & 4.8 & 2.3 \\
\hline Other & 4.8 & 5.7 & 0.9 & 2.7 & 4.7 \\
\hline Indirect taxes & 22.6 & 0.3 & 5.5 & 7.2 & 9.5 \\
\hline GDP at market prices & 4.8 & 4.5 & 3.7 & 5,0 & 5.5 \\
\hline
\end{tabular}


Table 3. Guinea: Gross Domestic Product at Current Prices by Demand Components, 1997-2001

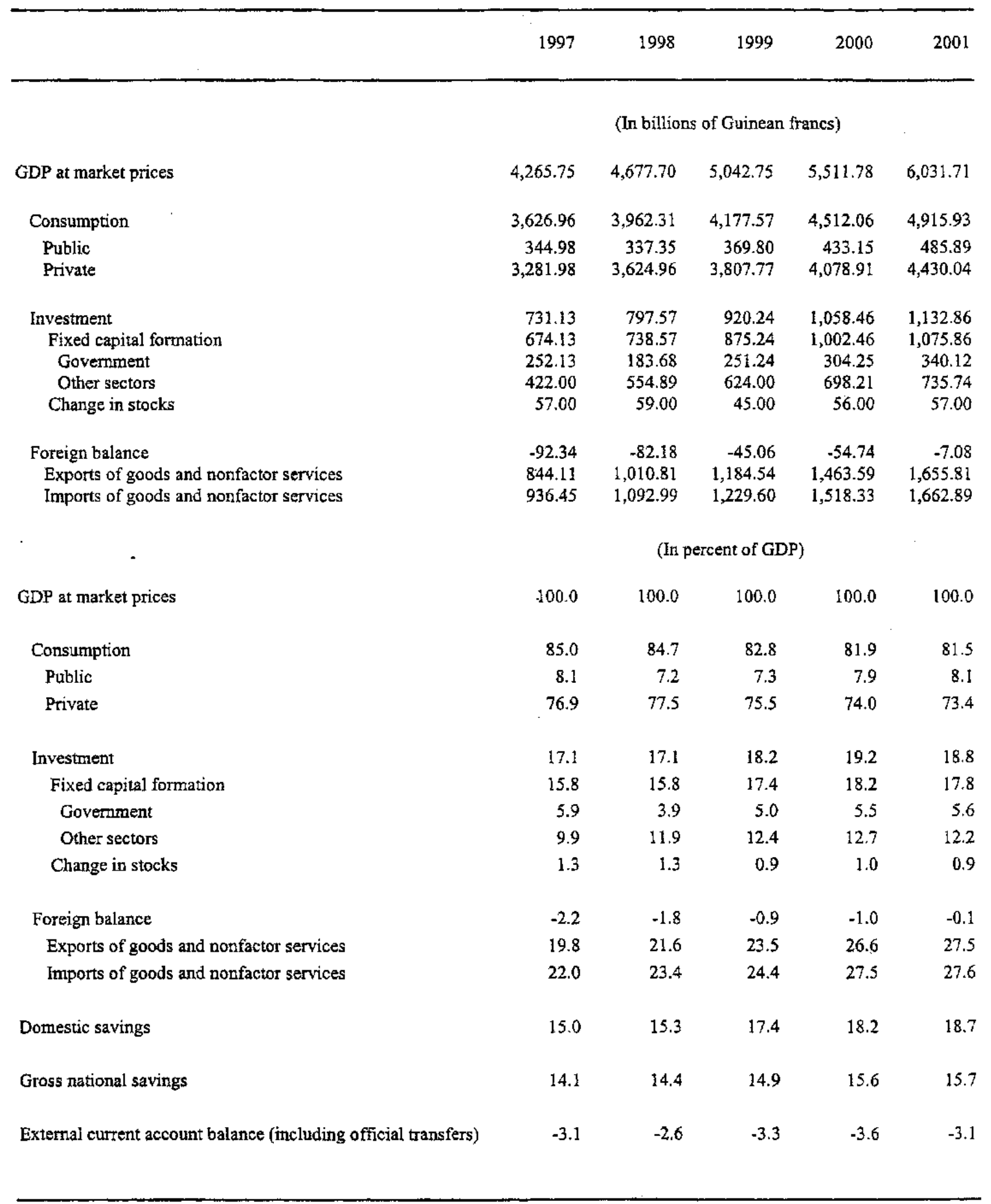


Table 4. Guinea: Financial Operations of the Central Government, 1997-2001

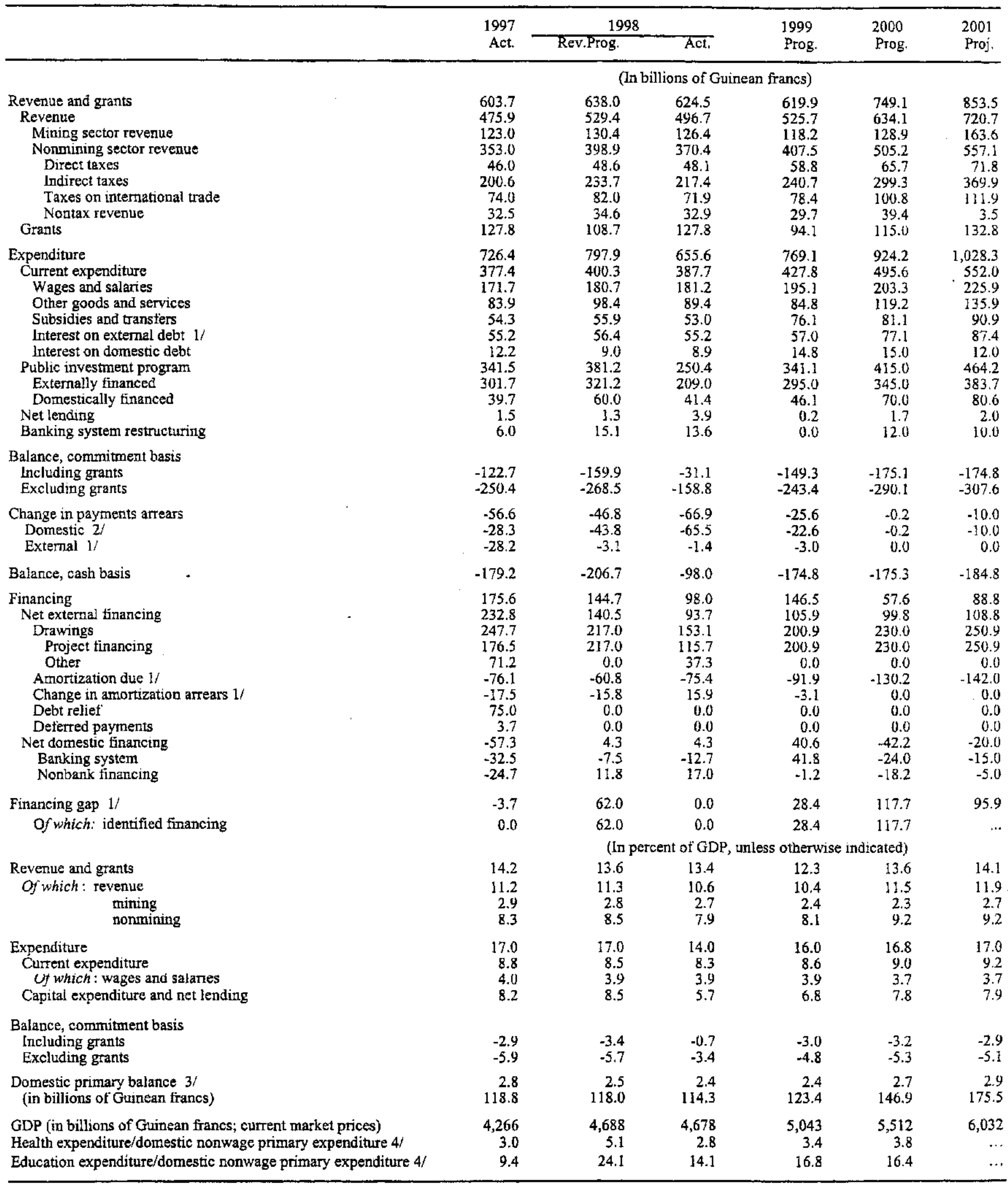

Sources: Guinean authorities; and staffe estimates and projections.

1/ For the 1998 program and the following years, the external debt service and change in extemal arrears refer to cash obligations only (after debt relief).

2/ Comprises the changes in outstanding domestic arrears and in the tloat between expenditure commitments and cash payments for the current fiscal year

3/ Revenue minus noninterest expendirure (excluding foreign-financed capital expenditure).

4/ In percent. 
Table 5. Guinea: Balance of Payments, 1997-2001

(In millions of U.S. dollars, unless otherwise indicated)

\begin{tabular}{|c|c|c|c|c|c|}
\hline & 1997 & $\begin{array}{r}1998 \\
\text { Est. }\end{array}$ & $\begin{array}{l}1999 \\
\text { Proj. }\end{array}$ & $\begin{array}{l}2000 \\
\text { Proj. }\end{array}$ & $\begin{array}{l}2001 \\
\text { Proj. }\end{array}$ \\
\hline Merchandise irade bajance & 87.5 & 137,4 & 174.4 & 189.1 & 230.1 \\
\hline Exports, f.o.b. & 660.0 & 709.2 & 754.5 & 823.4 & 889.8 \\
\hline Of which: mining products & 553.7 & 601.0 & 632,7 & 688.2 & 746.5 \\
\hline Imports, f.o.b. & -572.5 & -571.8 & .580 .1 & -634.3 & -659.7 \\
\hline Food products & -87.5 & 97.6 & -82.7 & -86.8 & -91.4 \\
\hline Other consuraption goods & -96.7 & -103.2 & -93.9 & -100.3 & -107.2 \\
\hline Petroleum goods & -85.1 & -71.3 & -90.5 & -101.4 & -91.5 \\
\hline Intermediate and capital goods & -303.2 & -299.7 & -313.1 & $-345,9$ & -369.6 \\
\hline Services trade balance & -171.8 & -204.1 & -207.4 & -224.4 & -234.5 \\
\hline Services exports & 110.7 & 110.8 & 113.1 & 120.8 & 129.2 \\
\hline Of which: transport & 47.4 & 48.7 & 49.7 & 53.7 & 58.1 \\
\hline Services imports & $-282,5$ & -314.9 & -320.4 & -345.2 & .363 .7 \\
\hline Of which: transport & $-124,3$ & -148.1 & -150.3 & -164.3 & .170 .9 \\
\hline Income balance & -123.0 & -128.5 & -152.6 & $-158,9$ & $-163,8$ \\
\hline Of which: divident payments & -46.2 & -60.1 & -82.4 & -88.4 & -93.8 \\
\hline interest on public debt $1 /$ & -59.1 & -53.5 & -55.3 & -55.6 & -55.1 \\
\hline Transfers & 88.0 & 95.4 & 62.0 & 67.8 & 54.1 \\
\hline Of which: official transfers & 124.9 & 127.6 & 93.1 & 98.7 & 81.7 \\
\hline \multicolumn{6}{|l|}{ Current account } \\
\hline Including public transfers & $-119,3$ & -99.8 & -123.5 & -126.4 & -114.0 \\
\hline Excluđaing pubiic transfers & -244.2 & -227.4 & -216.6 & -225.1 & -195.7 \\
\hline Capital movernents & 100.8 & 60.7 & 5.0 & 40.5 & 53.3 \\
\hline Public (medium and long tern) & 91.7 & 31.4 & -12.3 & 10.8 & 15.9 \\
\hline Project-reiated lozns & 161.1 & 93.9 & 147.1 & 148.4 & I54.4 \\
\hline Program financing & 69.0 & 43.8 & 0.0 & 0.0 & 0.0 \\
\hline Amortization due $\mathrm{l} /$ & -138.4 & -106.3 & -159.5 & -137.6 & -138.5 \\
\hline Public (shart term) & -35.4 & 0.0 & 0.0 & 0.0 & 0.0 \\
\hline Direct and other private investinent (net) & 44.5 & 29.3 & 17.3 & 29.7 & 37,4 \\
\hline Errors and omissions & -4.3 & -17.3 & 0.0 & 0.0 & 0.0 \\
\hline Overall balance & -22.8 & .56 .3 & -118.6 & .85 .9 & -60.7 \\
\hline Finanting & 22.8 & 56.3 & -418.0 & -47.5 & -37.4 \\
\hline \multicolumn{6}{|l|}{ Change in net official } \\
\hline reserves (increaso -) & -46.5 & 4.5 & 18.5 & -47.5 & -37.4 \\
\hline IMF (net) & 23.4 & 22.6 & -7.3 & -8.5 & -12.9 \\
\hline Other reserves (net) & -69.9 & -18.1 & 25.7 & -39.0 & .24 .5 \\
\hline Changes in arrears and government assets (net) $2 /$ & 2.8 & .82 .3 & $-478,7$ & 0.0 & 0.0 \\
\hline Debt relief $3 /$ & 66.5 & 134.1 & 42.3 & 0.0 & 0.0 \\
\hline Residual finarcing gap $2 /$ & 0.0 & 0.0 & 536.54 & 133.4 & 98.1 \\
\hline \multicolumn{6}{|l|}{ Memorandum items: } \\
\hline \multicolumn{6}{|l|}{ Current account-GDP ratio (in percent) } \\
\hline Ineluding public transfers & -3.1 & -2.6 & .3 .3 & -3.6 & -3.1 \\
\hline Excluding public transfers & -6.3 & -6.0 & -5.9 & -6.3 & -5.3 \\
\hline Exports of GNFS 4/-GDP ratio (in percent) & 19.8 & 21.6 & 23.5 & 26.6 & 27.5 \\
\hline Imports of GNFS 4/-GDP ratio (in percent) & -22.0 & -23.4 & -24.4 & -27.5 & -27.6 \\
\hline External medium-and long-tem public debt $5 /$ & $3,130.3$ & $3,441,6$ & $3,031.5$ & $3,164.9$ & $3,312.1$ \\
\hline In percent of GDP & 80.4 & 90.7 & 82.1 & $B 9.0$ & 89.2 \\
\hline Debt-service ratio $6 /$ & 25,6 & 19.5 & 24.8 & 20.5 & 19.0 \\
\hline Gross reserves & 225.5 & 248.0 & 220.1 & 257.6 & 298,5 \\
\hline In months of imports (GNFS) $4 /$ & 3.2 & 3.4 & 2.9 & 3.2 & 3.5 \\
\hline
\end{tabular}

Sources: Guintan authorities; and staff estimates and projections.

1/ For 1997-98, excluding debt-service payments to nan-Paris Club creditors with no rescheduling agreement. From I999 onwards incjuding debt service payments on publie guaranteed debt.

2/ The total amount of arrears outstanding and the terms on which they should be rescheduled are disputed. The balance of payments follows the Guin proposals for rescheduling this debt. Detaits of the proposals of some of the creditors will be discussed in the preliminary FllPC initiative document ln the case of Russia, rescheduling is to be based on 270 percem discount on pre-1992 debt. The remaining and credits from non-Paris Club creditors are assumed to be rescheduled on terms at least comparable to those of the 1997 Paris Club Agreement. The conseguent debt relief is expected to fill most of the residual financing gap.

3/ Including the forgiveness component of the debt buyback of Argentina's debt. The presentation assumes that the debt buyback of commercial deht was completed in 1998 even though some aspects of the transaction were finalized in early 1999.

$4 /$ Goods and non-factor services.

5/ Including public guaranteed debr from 1998 onward, 1997 data do not fully capture debs to non-Paris Club bilaterals.

$6 /$ In percent of exports of goods and nonfactor services. 
Table 6. Guinea: Monetary Survey, 1997-2000

(In billions of Guinean francs, unless otherwise incicated)

\begin{tabular}{|c|c|c|c|c|c|c|c|c|c|c|}
\hline & \multirow{3}{*}{$\begin{array}{l}1997 \\
\text { Dec. }\end{array}$} & \multirow{3}{*}{$\begin{array}{l}\text { L998 } \\
\text { Dec. }\end{array}$} & \multirow{3}{*}{$\frac{1999}{\text { Mar. }}$} & \multicolumn{3}{|c|}{1999} & \multicolumn{4}{|c|}{2000} \\
\hline 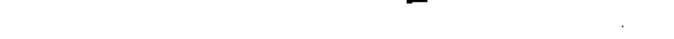 & & & & \multirow[t]{2}{*}{ Jun. } & \multirow[t]{2}{*}{ Sep. } & Dec. & Mar. & Jung. & Sep. & Dec. \\
\hline & & & & & & \multicolumn{5}{|c|}{ Progr. } \\
\hline \multicolumn{11}{|l|}{ Central banik } \\
\hline Net foreign assets & 135.2 & 146.0 & 124.3 & 110.8 & 108.4 & 130.6 & 140.3 & 163.0 & 184.6 & 196.4 \\
\hline (in millions of U.S. dollars) & $\mathrm{t} 18.2$ & 113.6 & 94.7 & 82.8 & 75.4 & 84.2 & 88.2 & 100.0 & 108.6 & 109.7 \\
\hline Net domestic assets & 88.6 & {$[09.3$} & 148.1 & 169.8 & 158.9 & 151.9 & 147.0 & 130.1 & 114.8 & 110.8 \\
\hline Domestic credit & B1.1 & 91.8 & 108.6 & 143.9 & 132.2 & 134.6 & 132.9 & 119.5 & 111.3 & 107.9 \\
\hline Government (net) & 85.7 & 74.8 & 94.1 & 125.9 & 118.0 & 118.8 & 118.8 & 105.8 & 94.8 & 94.8 \\
\hline \multicolumn{11}{|l|}{ Of which } \\
\hline Gold revalustion claims & 17.6 & 17.6 & 17.6 & 17.6 & 17.6 & 17.6 & 17.6 & 17.6 & 17.6 & 17.6 \\
\hline Public enterprises & 4.7 & 4.5 & 4.5 & 6.7 & 6.7 & 6.6 & 6.0 & 6.0 & 6.0 & 6.0 \\
\hline Private sector & 3.4 & 5.8 & 4.3 & 6.9 & 8.2 & 5.3 & 5.0 & 4.7 & 6.0 & 4.1 \\
\hline $\begin{array}{l}\text { Claims on deposit money banks } \\
\text { Of which }\end{array}$ & -12.7 & 6.7 & 5.6 & 4.5 & -0.7 & 3.9 & 3.0 & 3.0 & 4.4 & 3.0 \\
\hline Sterilization bills (-) & -21.3 & 0.0 & 0.0 & 0.0 & -4.5 & 0.0 & 0.0 & 0.0 & 0.0 & 0.0 \\
\hline Other items, net (assets +) & 7.6 & 17.5 & 39.5 & 25.9 & 26.7 & 17,3 & 14.1 & 10.6 & 3.6 & 2.9 \\
\hline Reserve money & 223.8 & 255.2 & 272.3 & 280.6 & 267.3 & 282.5 & 287.3 & 293.1 & 299.5 & 307.2 \\
\hline Curency outside banks & 191.6 & 208.0 & 220.4 & 234,1 & 221.4 & 235.1 & 239.8 & 245.6 & 251.5 & 257.3 \\
\hline Bank reserves & 27.0 & 44.6 & 37.8 & 44.1 & 41.7 & 43.4 & 42.5 & 44.2 & 44.4 & 46.4 \\
\hline Deposits & 20.1 & 39.1 & 30.5 & 36.0 & 35.6 & 37.5 & 36.6 & 38.2 & 38.4 & 40.4 \\
\hline Cash in till & 6.9 & 5.5 & 7.3 & 8.1 & 6.2 & 5.9 & 5.9 & 5.9 & 6.0 & 6.0 \\
\hline Private sector deposits & 5.2 & 2.7 & 5.1 & 2.4 & 4.1 & 4.0 & 5.0 & 3.3 & 3.6 & 3.5 \\
\hline \multicolumn{11}{|l|}{ Deposit money banks } \\
\hline Net foreign assets & 22.0 & 34.4 & 44.7 & 44.7 & 21.3 & 30.0 & 31.3 & 32.5 & 33.3 & 35.0 \\
\hline Bank reserves & 24.9 & 50.1 & $\$ 5.1$ & 38.3 & 44.0 & 43.4 & 42.5 & 44.2 & 44.4 & 46.4 \\
\hline Deposits at the central bank & 18.0 & 44.6 & 37.8 & 30.2 & 37.8 & 37.5 & 36.6 & 38.2 & 38.4 & 40.4 \\
\hline Cash is till & 6.9 & 5.5 & 7.3 & 8.1 & 6.2 & 5.9 & 5.9 & 5.9 & 6.0 & 6.0 \\
\hline Liabilities to central back (-) & 10.6 & -7.2 & -8.2 & -5.3 & $-3,4$ & -3.9 & -3.0 & -3.0 & -4.4 & -3.0 \\
\hline Of whiteh & & & & & & & & & & \\
\hline Sterilization biris & 21.3 & 0.0 & 0.0 & 0.0 & 4.5 & 0.0 & 0.0 & 0.0 & 0.0 & 0.0 \\
\hline Domestic credit & 211.1 & 238.0 & 234.8 & 249.2 & 251.3 & 266.6 & 273.4 & 280.1 & 289.3 & 291.0 \\
\hline Credit to the government & 26.8 & 23.6 & 30.5 & 31.5 & 24.9 & 21.3 & 21.3 & 21.3 & 21.3 & 21.3 \\
\hline Claims & 46.8 & 47.2 & 53.4 & 53.7 & 61.0 & 47.2 & $\ldots$ & $\ldots$ & $\ldots$ & $\ldots$ \\
\hline Deposits & 20.0 & 23.6 & 22.9 & 22.1 & 36.2 & 25.9 & $\ldots$ & $\ldots$ & $\ldots$ & $\ldots$ \\
\hline Claims on public enterprises & 0.3 & 0.3 & 0,4 & 1,7 & 0.0 & 0.0 & 0.3 & 0.3 & 0.3 & 0.3 \\
\hline Claims on the private sector & 184.2 & 214.1 & 204.0 & 215.9 & 226.5 & 245.3 & 251.7 & 258.5 & 267.7 & 269,3 \\
\hline Other iterns, Det (assets +) & -54.3 & -90.0 & -89.6 & -88.2 & -79.9 & -97.8 & -99.6 & -101.5 & .104 .9 & -105.0 \\
\hline Liabilities to the private sector & 213.9 & 225.2 & 226.8 & 238.7 & 233.3 & $23 \mathrm{~B} .3$ & 244.6 & 252.3 & 258.1 & 264.3 \\
\hline \multicolumn{11}{|l|}{ Monetary survey } \\
\hline Net foreign assets & 157.2 & 180.4 & 169.0 & 155.5 & 129.7 & 160.6 & 171.6 & 195.5 & 218.4 & 231.4 \\
\hline Net domestic assets & 253.5 & 255.5 & 292.4 & 319.7 & 329.1 & 316.8 & 317.8 & 305.8 & 294.8 & 293.8 \\
\hline Domestic credit & 304.8 & 323.1 & 337.7 & 388.6 & 384.2 & 397.3 & 403.3 & 396.7 & 396.2 & 395.9 \\
\hline Credit to the govetnment & 112.5 & 98.4 & 124.6 & 157.4 & 142,8 & 140.2 & 140.2 & 127.2 & 116.2 & 116.2 \\
\hline (Excluding gold revalustion claims) & 94.9 & 80.8 & 107.0 & 139.8 & 125.2 & 122.6 & 122.6 & 109.6 & 98.6 & 98.6 \\
\hline Claims on public enterprises & 4,9 & 4.8 & 4.9 & 8.4 & 6.7 & 6.6 & 6.3 & 6.3 & 6.3 & 6.3 \\
\hline Claims on the private sector & 187.4 & 219.8 & 208.2 & 222.8 & 234.7 & 250.5 & 256.8 & 263.2 & 273.7 & 273.4 \\
\hline Other items, net (assets +) & -51.3 & -67.6 & -45.4 & -68.9 & $\cdot 55.1$ & -80.5 & -85.5 & -90.9 & -101.3 & -102.1 \\
\hline \multicolumn{11}{|l|}{ Of which } \\
\hline Discrepancy between central bank and deposit money banks & -4.2 & 5.0 & 4.7 & .5 .6 & -1.9 & 0.0 & 0.0 & 0.0 & 0,0 & 0.0 \\
\hline Broad money (M2) & 410.7 & 435.8 & 461.4 & 475.2 & 458.8 & 477.4 & 489.3 & 501.3 & 513.2 & 525.1 \\
\hline Curracy & 191.6 & 208.0 & 229.4 & 234.1 & 221.4 & 235.1 & 239.8 & 245.6 & 251.5 & 257.3 \\
\hline Deposits & 219.1 & 227.9 & 231.9 & 241.1 & 237.4 & 242.3 & 249.6 & 255.6 & 261.7 & 267.8 \\
\hline Of which & & & & & & & & & & \\
\hline Foreign clirtency deposits & $\$ 3.4$ & 56.6 & 67.2 & 69.8 & 62.8 & 63.0 & 64.9 & 66.5 & 68.1 & 69.6 \\
\hline Memorandum items & & & & & & & & & & \\
\hline Gross reserves (in months of imports) & 3.2 & 3.4 & 3.0 & 2.8 & 2.7 & 2.9 & 2.7 & 3.0 & 3.1 & 3.2 \\
\hline Gross reserves (in percent of broad money) & 62.8 & 73.9 & 63.3 & 58.9 & 63.6 & 71.6 & 72.9 & 79.0 & 83.3 & 87.8 \\
\hline Bread monty (12-month change in percent) & 17.3 & 6.1 & 10.5 & 11.4 & 2.6 & 9.5 & 6.1 & 5.5 & 11.9 & 10.0 \\
\hline Reserve money (12-month change in percent) & 15.1 & 14.0 & 20.7 & 20.6 & 10.3 & 10.7 & 5.5 & 4.5 & 12.0 & 8.7 \\
\hline Velocity (GDP/average M2) & 11.1 & 10.6 & $\cdots$ & $\ldots$ & $\cdots$ & 10.8 & $m$ & $\cdots$ & $\cdots$ & 110 \\
\hline
\end{tabular}

Sources: Guinean authorities; and staff estimates and projections. 
Table 7. Guinea: Indicators of Fund Credit and Debt Servicing, 1995-2006

\begin{tabular}{|c|c|c|c|c|c|c|c|c|c|c|c|c|}
\hline & 1995 & 1996 & 1997 & 1998 & 1999 & 2000 & 2001 & 2002 & 2003 & 2004 & 2005 & 2006 \\
\hline & \multicolumn{12}{|c|}{ (In percent) } \\
\hline Outstanding Fund credit/quota $1 /$ & 80.2 & 72.8 & 93.3 & 114.4 & 79.2 & 73.5 & 64.9 & 56.7 & 45.8 & 31.6 & 19.9 & 11.1 \\
\hline Outstanding Fund credit/GDP $1 /$ & 2.6 & 2.1 & 2.6 & 3.2 & 3.1 & 3.0 & 2.6 & 2.1 & 1.6 & 1.0 & 0.6 & 0.3 \\
\hline $\begin{array}{l}\text { Outstanding Fund credit/exports } \\
\text { of goods and nonfactor services }\end{array}$ & 12.5 & 11.3 & 13.1 & 14.9 & 13.4 & 11.4 & 9.4 & 7.8 & 5.8 & 3.8 & 2.2 & 1.1 \\
\hline \multicolumn{13}{|l|}{$\begin{array}{l}\text { Debt service to the Fund/total } \\
\text { debt service on public and }\end{array}$} \\
\hline public-guaranteed debt $2 /$ & 5.1 & 5.4 & 5.9 & 6.4 & 3.9 & 4.8 & 6.9 & 6.6 & 8.6 & 11.6 & 10.6 & 8.3 \\
\hline $\begin{array}{l}\text { Debt service to the Fund/gross } \\
\text { official reserves } 2 /\end{array}$ & 5.1 & 5.1 & 5.4 & 4.3 & 3.9 & 3.8 & 4.8 & 4.2 & 5.2 & 6.2 & 4.7 & 3.3 \\
\hline $\begin{array}{l}\text { Debt service ratio on public and } \\
\text { public-guaranteed debt } 2 /\end{array}$ & 25.8 & 25.1 & 27.1 & 20.6 & 25.6 & 21.3 & 20.3 & 18.6 & 17.5 & 15.3 & 13.0 & 11.7 \\
\hline Memorandum items: & \multicolumn{12}{|c|}{ (In millions of SDRs) } \\
\hline Exports of goods and nonfactor services & 505.1 & 507.5 & 560.1 & 604.8 & 633.3 & 689.7 & 739.4 & 784.1 & 839.4 & 899.2 & 963.5 & $1,032.4$ \\
\hline Total Fund credit outstanding & 63.1 & 57.3 & 73.4 & 90.1 & 84.9 & 78.8 & 69.5 & 60.8 & 49.1 & 33.9 & 21.3 & 11.9 \\
\hline $\begin{array}{l}\text { Total debt service on public and } \\
\text { public guaranteed debt }\end{array}$ & 130.3 & 127.6 & 151.5 & 124.8 & 162.1 & 147.2 & 149.8 & 145.8 & 147.2 & 137.7 & 125.0 & 121.2 \\
\hline Of which: IMF & 6.7 & 6.9 & 8.9 & 7.9 & 6.3 & 7.1 & 10.3 & 9.6 & 12.6 & 16.0 & 13.3 & 10.1 \\
\hline Gross official reserves & 130.2 & 136.7 & 163.9 & 182.9 & 160.7 & 188.1 & 216.6 & 230.1 & 244.5 & 260.0 & 284.6 & 304.2 \\
\hline Nominal GDP & 2458.0 & 2726.8 & 2830.4 & 2798.7 & 2695.9 & 2597.5 & 2693.6 & 2891.4 & 3099.4 & 3324.9 & 3567.1 & 3827.1 \\
\hline
\end{tabular}

Sources: IMF, Treasurer's Department; and staff estimates and projections.

1/ Outstanding Fund credit includes SAF/ESAF loans and outstanding purchases at year's end.

2/ Debt service in percent of exports of goods and nonfactor services. 
Table 8. Social Indicators in Guinea and Sub-Saharan Africa, 1997

\begin{tabular}{lrr}
\hline & Guinea & $\begin{array}{c}\text { Sub-Saharan } \\
\text { Africa }\end{array}$ \\
\hline GNP per capita (U.S. dollars) & 550 & 510 \\
Life expectancy at birth (years) & 46 & 51 \\
Infant mortality (per 1,000) & 120 & 91 \\
Maternal mortality (per 1,000,000) & 880 & 700 \\
Illiteracy (percent of age 15+) & 76 & 43 \\
Gross primary enrollment (percent of & 51 & 72 \\
age group) & 37 & 65 \\
Of which: female & 55 & 47 \\
Access to safe water (percent) & & \\
\hline
\end{tabular}




\section{Guinea: Third Annual Arrangement Under the Enhanced Structural Adjustment Facility}

Attached hereto is a letter dated December 7, 1999 (hereinafter the "Letter"), with an annexed memorandum on economic and financial policies for 1999/2000 (hereinafter the "Memorandum"), from the Minister of Economy and Finance and Governor of the Central Bank, requesting from the International Monetary Fund the third annual arrangement under the Enhanced Structural Adjustment Facility, and setting forth the objectives and policies of the program to be supported by that arrangement.

To support these objectives and policies, the Fund grants the requested arrangement in accordance with the following provisions, and subject to the Instrument to Establish the Enhanced Structural Adjustment Facility Trust, as amended:

1. Under the third annual arrangement, Guinea will have the right to request three loans totaling SDR 23.6 million as follows:

(a) the first loan, in an amount equivalent to SDR _ million, will be available on or after 1999 at the request of Guinea;

(b) the second loan, in an amount equivalent to SDR million, will be available on June 30,2000 at the request of Guinea subject to paragraph 2 below; and

(c) the third loan, in an amount equivalent to SDR million, will be available on December 31, 2000 at the request of Guinea subject to paragraph 2 below.

2. Guinea will not request disbursement of the second loan and the third loan specified in paragraphs $1(\mathrm{~b})$ and $1(\mathrm{c})$, respectively

(a) if the Managing Director finds that, with respect to the second loan, the data as of March 31,2000, and, with respect to the third loan, the data as of September 30,2000, indicate that

(i) the floor on the central government primary balance, or

(ii) the ceiling on net bank credit to the government, or

(iii) the ceiling on reserve money, or

(iv) the floor on net foreign assets of the Central Bank, or 
(v) the ceiling on new medium and long term nonconcessional external loans contracted or guaranteed by the government or the Central Bank, or

(vi) the ceiling on short-term external debt outstanding contracted or guaranteed by the government or the Central Bank

specified in Table 1 of the Memorandum is not observed; or

(b) If by February 15, 2000, Guinea has not produced statistics on preliminary treasury balance for end-January 2000 as specified in Table 2 of the Memorandum; or

(c) If by March 15, 2000, Guinea has not produced statistics on preliminary treasury balance for end-February 2000 as specified in Table 2 of the Memorandum; or

(d) If by January 15,2000 , the computerized expenditure system at the Ministry of Finance of Guinea has not begun functioning as specified in Table 2 of the Memorandum; or

(e) If by March 31, 2000, Guinea has not published customs clearance procedures for airports as specified in Table 2 of the Memorandum; or

(f) If by March 31, 2000, Guinea has not initiated an audit of the Central Bank as specified in Table 2 of the Memorandum; or

(g) If by March 31, 2000, Guinea has not reached a decision on the reform strategy for the National Agency for Developing Mining Infrastructure and has not adopted an action plan for implementing such strategy as specified in Table 2 of the Memorandum; or

(h) If by December 31,1999, Guinea has not established an anticorruption committee as specified in Table 2 of the Memorandum; or

(i) If at any time during the period of the third annual arrangement, Guinea accumulates any new external payments arrears except for the reschedulable amounts described in paragraph 30 of the Memorandum; or

(j) If Guinea

(i) has imposed or intensified restrictions on payments and transfers for current international transactions, or

(ii) has introduced or modified multiple currency practices, or 
(iii) has concluded bilateral payments agreements that are inconsistent with Article VIII, or

(iv) has imposed or intensified import restrictions for balance of payments reasons; or

(k) after June 29, 2000 with respect to the second loan and after December 30, 2000 with respect to the third loan, until the Fund has determined that the reviews contemplated in paragraph 32 of the Memorandum have been completed.

If the Managing Director finds that any of the performance clauses that have been established in or under this paragraph 2 have not been met, the second loan or the third loan specified in paragraphs 1 (b) or 1 (c), respectively, may be made available only after consultation has taken place between the Fund and Guinea, and understandings have been reached regarding the circumstances in which Guinea may request the disbursement of that loan.

3. In accordance with paragraph 3 of the Letter, Guinea will provide the Fund with such information as the Fund requests in connection with the progress of Guinea in implementing the policies and reaching the objectives supported by this arrangement.

4. In accordance with paragraph 4 of the Letter, during the period of the third annual arrangement, Guinea will consult with the Managing Director on the adoption of any measures that may be appropriate at the initiative of the government or whenever the Managing Director requests such a consultation. Moreover, after the period of the third annual arrangement and while Guinea has outstanding financial obligations to the Fund arising from loans under that arrangement, Guinea will consult with the Fund from time to time, at the initiative of the government or whenever the Managing Director requests consultation on Guinea's economic and financial policies. These consultations may include correspondence and visits of officials of the Fund to Guinea or of representatives of Guinea to the Fund. 
Mr. Michel Camdessus

Managing Director

International Monetary Fund

Washington, D.C. 20431

U.S.A.

Dear Mr. Camdessus:

1. The objectives of Guinea's program of economic and financial adjustment for the three-year period 1999-2001 are set out in the updated policy framework paper prepared in close collaboration with the staffs of the Fund and the World Bank, which is being transmitted to you under separate cover.

2. The attached memorandum of economic and financial policies, based on the policy framework paper referred to above, sets out the objectives and policies that the government of Guinea intends to pursue during 1999-2000. In support of these objectives and policies, the government hereby requests the third annual arrangement under the Enhanced Structural Adjustment Facility (ESAF) in an amount equivalent to SDR 23.6 million (30 percent of quota). In this context, Guinea also requests an extension of the original three-year ESAF commitment period to January 12, 2001.

3. The government of Guinea will provide the Fund with such information as the Fund requests in connection with the progress made in implementing the economic and financial policies and achieving the objectives of the program.

4. The government of Guinea believes that the policies and measures set out in the attached memorandum are adequate to achieve the objectives of its program; it will take any further measures that may become appropriate for this purpose. During the period of the third annual ESAF arrangement, the government will consult with the Managing Director on the adoption of any measures that could be appropriate, at the initiative of the government or whenever the Managing Director requests such a consultation. Moreover, after the period of the third annual ESAF arrangement and while Guinea has outstanding financial obligations to the Fund arising from loans under the arrangement, the government will consult with the Fund from time to time, at the initiative of the government or whenever the Managing Director requests consultation on Guinea's economic and financial policies. 
5. The government of Guinea will conduct with the Fund the first review of its program supported by the third annual arrangement not later than June 30,2000 and the second review net later than December 31, 2000.

\section{Sincerely yours,}

$$
/ \mathbf{s} /
$$

Ibrahima Kassory Fofana Minister of Economy and Finance

$$
/ \mathrm{s} /
$$

\section{Chérif Bah}

Governor of the Central Bank of Guinea

Attachment 
CONFIDENTIAL

\author{
Memorandum of Economic and Financial Policies \\ of the Government of Guinea for the Remainder of 1999 and for 2000
}

\title{
I. INTRODUCTION
}

1. In the context of the three-year arrangement under the Enhanced Structural Adjustment Facility (ESAF), approved by the International Monetary Fund on January 13, 1997, the government of Guinea's economic and financial program for 1998 was supported by the second annual arrangement approved on April 3, 1998. The third annual arrangement was to have supported the program for 1999; unfortunately, the economic and financial situation deteriorated in the early months of 1999 , requiring corrective measures. As the situation has since stabilized, the government is hereby presenting a program for the period October 1, 1999-September 30, 2000 for which IMF support is requested.

2. This memorandum describes the implementation of the 1998 program, as well as economic developments in Guinea during this period and the first eight months of 1999. Furthermore, it sets out the objectives that the government of Guinea intends to achieve during the remainder of 1999 and in 2000 and the accompanying policies. The structural adjustment program for 1999-2000, in support of which the government of Guinea requests the third annual arrangement under the ESAF, is cast within a medium-term framework outlined in the updated policy framework paper (PFP) for 1999-2001. The program remains focused on creating an enabling environment for private sector development, which will be the engine of economic growth in Guinea.

\section{Program Implementation During 1998}

3. In 1998, several events had an impact on economic activity. First, the preparations for the presidential elections on December 14 slowed economic activity. In addition, there was a serious deterioration in security in the region, as well as a downturn in world prices for Guinean exports, particularly bauxite and gold. Thus, real GDP growth of 4.5 percent was slightly lower than in 1997, while inflation, as measured by the change in the Conakry price index on a year-over-year basis, stood at 4.5 percent, as compared to 5.2 percent in 1997.

4. Most of the financial and structural benchmarks for December 31, 1998 were observed, except for the targets on net foreign assets of the Central Bank of the Republic of Guinea (BCRG), external debt arrears, and nonmining government income. The reporting of public expenditure commitments, payment orders and payments was done in a timely fashion. Nevertheless, the results had to be corrected manually due to continuing problems with the computer system. 
5. The budget situation was very difficult, particularly at year-end, on account of delays in foreign aid disbursements and lower-than-expected revenue, which reached 10.6 percent of GDP (i.e. a shortfall of 0.7 percent of GDP compared with the program), essentially owing to low trade tax receipts. Furthermore, because of the pressure on expenditure as a result of the elections and the security situation in the subregion, certain 1998 commitments had to be carried over to 1999 to achieve the primary surplus target. Unavoidable overruns in budgetary appropriations (particularly for maintaining security in the subregion) led to lowerthan-anticipated spending in the priority sectors of health and education. The government did, however, release its contribution to the restructuring of banks in difficulty and reduce its domestic arrears, partly by issuing bonds to its suppliers.

6. In the monetary area, the money supply (M2) grew by 6.1 percent during 1998 , as compared with 11.4 percent in the revised program. This lower-than-expected increase reflected a smaller accumulation of net foreign assets as well as a more substantial reduction in the banking sector's net credit to the government, which more than compensated for a larger expansion of credit to the private sector. The central bank was unable to reach its net foreign assets target owing to the difficulties in buying foreign exchange on the interbank market, which was not operational, while the banks accumulated foreign reserves. The reference exchange rate for the Guinean franc, as calculated by the BCRG, depreciated by 12 percent on average during the year relative to the U.S. dollar, while the gap between the reference rate and the parallel market rate widened at the end of the year, to more than 10 percent.

7. In the external sector, the current account deficit, excluding official transfers, declined slightly to the equivalent of 6 percent of GDP, reflecting both an increase in exports and a contraction in imports, the latter of which was linked to a slowdown in the public investment program. All bilateral agreements with Paris Club members (except Russia) under the 1997 debt rescheduling were signed. Nevertheless, the existence of external arrears at least partially attributable to breakdowns in the monitoring of external debt, led to a delay in the disbursement of the 1998 tranche of the Paris Club rescheduling; it was finally released in August 1999 after all arrears had been cleared. The commercial debt buy back operation was completed with World Bank support and the debt buy back operation with Argentina was finalized. Little progress was made in the discussions on the rescheduling of Russian debt.

8. Structural reforms continued in 1998-99 according to the program timetable. The rehabilitation of three ailing banks was a qualified success. Their operations continued to be restructured under central bank supervision and while two of them made progress, the third still faces problems. The recapitalization of two banks was completed as programmed. As for the third, the government paid up its shares but the other shareholders are delaying their contributions. Furthermore, liquidation of the Banque Internationale pour l'Afrique en Guinée (BIAG) is nearing completion.

9. The anticipated strengthening of bank supervision took place according to schedule. Bank inspection, in particular, was reinforced through the restructuring of the BCRG's Inspection Department and the creation of a group of bank and insurance inspectors recruited 
by competitive examination. The government also gave responsibility for the supervision of micro-finance institutions to the BCRG.

10. Other structural reforms have generally progressed as expected. The court of arbitration has commenced operations. The restructuring plan for the CNSS was adopted by the Council of Ministers in November 1998, and the restructuring of the financial and accounting departments is under way. However, efforts to sell savings bonds to the private sector to encourage domestic saving were delayed to April 1999 and have not been very successful.

\section{ECONOMIC AND FINANCIAL DEVELOPMENTS FROM JANUARY-AUGUST 1999}

11. The wait-and-see attitude of economic agents observed during the election period in the last quarter of 1998 continued throughout the early months of 1999, and security in the subregion did not improve as had been hoped. At the same time, the government's financial situation deteriorated significantly. The lack of foreign aid and a continued weak revenue performance, combined with the aforementioned carryover of certain expenditure commitments from 1998 and the increase in costs resulting from Guinea's military engagement in Sierra Leone and Guinea Bissau, meant that in the first four months of the year the government had to resort to banking system financing equivalent to 1.4 percent of GDP; this was accompanied by a monetary expansion of 8.8 percent and a decline in net foreign assets of the BCRG of US\$33.3 million to US\$80.5 million at end-April.

12. To stem this deterioration, the authorities, in consultation with MMF staff, decided to have a period of consolidation during which they could restore rigorous financial management before presenting a new program for IMF support. Expenditure controls were strengthened and the expenditure monitoring system fine-tuned. Measures were also taken to improve tax administration, particularly in the customs area, where recommendations of the April 1999 MF technical assistance mission began to be implemented. Monthly fiscal and monetary targets were also established to guide the government's financial recovery.

13. End-August 1999 results were close to the targets set, reflecting a more stable macroeconomic and financial situation. Despite a sudden drop in the tax yield on petroleum products, which was adversely affected by the increase in the world prices and by the deterioration in the exchange rate, budgetary revenue collected during the period May-August 1999 was 8 percent larger than in the preceding four months and the primary surplus amounted to GF 64 billion, or more than three times the level reached at end-April. Net banking system credit to the government was reduced from GF 167.9 billion at end-April to GF 137.4 billion, while the BCRG's net foreign assets remained at their end-April level of US\$80.8 million.

14. Revenue in September was weaker than envisaged, particularly customs receipts which declined as a result of an erosion of taxable imports. As a result, banking system credit 
to the government increased to GF 142.8 billion at end-September, while net foreign assets of BCRG declined to US\$75.4 million.

15. On the structural reform side, the main actions in the first eight months of the year involved the preparation of a new computerized expenditure system with technical and financial assistance from various donors (World Bank, Canada, and the European Union), and the launching of a foreign exchange auction on September 1, 1999.

\section{ECONOMIC PROGRAM FOR END-1999 AND 2000}

16. The last months of $\mathbf{1 9 9 9}$ will continue to be difficult for Guinea because of the high prices of petroleum products and the risks related to the ongoing conflicts in neighboring countries. Despite a good performance in the mining sector, growth projections for the year have been revised downward to 3.7 percent in real terms on account of weaker-thananticipated activity particularly in the services sector; consumer prices are expected to increase by 4.5 percent on average in 1999. Given limited prospects for external aid from now until the end of the year and continued tight fiscal policies, the current account deficit (excluding official transfers) is expected to be 6 percent of GDP, while external reserves at year end should cover the equivalent of about three months of imports.

17. To achieve these goals, the target for the primary surplus has been set at 2.4 percent of GDP, the same level as in 1998. Given the weak revenue performance in September, revenue for 1999 is projected at 10.4 percent of GDP, despite an increase in the prices at the pump to restore tax receipts on petroleum products. Expenditures will be compressed so as to maintain the primary surplus target, while maintaining spending in the priority sectors (particularly where such spending is a condition for mobilizing European Union financial assistance), and accounting for the additional costs associated with maintaining security along Guinea's borders, where there have recently been new incursions from neighboring countries. The money supply growth target has been limited to 9.5 percent for the year. Government credit will fall from GF 142.8 billion at end-September to GF 140.2 billion at end-December 1999, which will allow net foreign assets of the BCRG to increase from US\$75.4 million to US\$84.2 million over the same period.

18. Some improvement in the world price for bauxite and the expected resumption of international aid allows for a more optimistic outlook for 2000 . The authorities are determined to deepen and accelerate the current structural reforms, particularly in the areas of government finance management, public sector reform, and strengthening of the banking supervision system. They are also determined to improve governance and pursue the stabilization of the country's financial situation.

19. The government's program for 2000 is based on a projected 5 percent growth of real GDP, stemming from an increase in value added in the fisheries, water, and electricity (particularly with the completion of the Garafiri dam). The program aims at reducing inflation, as measured by the Conakry consumer price index, to an end-period rate of 
4 percent, containing the current account deficit (excluding official transfers) at 6.3 percent of GDP, and bringing gross external reserves to the equivalent of some 3.2 months of imports.

\section{A. Financial Policies}

20. To achieve the program's macroeconomic objectives for 2000 , the primary budgetary surplus on a commitment basis will increase to 2.7 percent of GDP (GF 147 billion, i.e., an improvement of $1 / 3$ percentage point of GDP compared with 1999), corresponding to an overall deficit (excluding grants) of 5.3 percent of GDP (GF 290 billion). The primary surplus will not be sufficient to finance external and domestic debt service obligations (GF 298 billion and GF 15 billion, respectively) and the programmed net reduction in: (i) domestic payments arrears (GF 0.2 billion); (ii) government indebtedness to the Guinean banking system (GF 24 billion); and (iii) domestic debt to the private sector (GF 8.2 billion), leaving a financing gap estimated at GF 118 billion. Budgetary aid already identified amounts to GF 87 billion, leaving a supplementary financing gap of approximately GF 31 billion (US\$20 million), which could come from a new rescheduling by the Paris Club.

21. Revenue is forecast to amount to 11.5 percent of GDP (GF 634 billion), an improvement of more than one percentage point of GDP. This increase should result from improved nonmining revenue following the introduction of measures by customs to improve supervision of exemptions and imports, particularly under the simplified procedures for the informal sector. These measures, which were recommended by the IMF Fiscal Affairs technical assistance mission, will be implemented according to the attached timetable (Table 3), with help from IMF technical assistance already in Conakry. For its part, the tax directorate will continue to improve the efficiency of its staff and will strengthen the collection of nontax revenue.

22. Total primary expenditure has been limited to 8.8 percent of GDP (GF 487 billion), against 8.0 percent in 1999 . This slight increase takes account of the spending required to maintain security in the subregion and defend the nation, as well as that required for the general and local elections initially scheduled for December 1999. It also takes account of nonwage operating expenditure of the priority sectors, which will increase from GF 48.3 billion in 1999 to GF 57 billion in 2000 . The wage bill would increase by 4.3 percent, reflecting the full-year effect of 1999 army promotions, and the 7 percent civil service raise granted on October 1, 1999, as well as the new recruitment in education.

23. Reforms intended to improve budgetary management and public accounting will continue, with a special focus on treasury reform and computerization. Key to these efforts will be the introduction, with donor support, of a new computerized expenditure monitoring system that is both more efficient and less costly to maintain than the current system; it should become operational before January 15, 2000 for the core offices of the Ministry of Finance and on June 30,2000 for all ministries. It will allow for fully automated, and hence more rigorous, monitoring of expenditure. The treasury reform is designed to give accounting 
officers more responsibility in operations, while allowing the Treasury Director to fulfill his role of organizing and monitoring their work. This reorganization is aimed at ensuring the regular production of consolidated monthly balances for the treasury, and thus more timely expenditure management. To increase budget transparency, a new budgetary nomenclature was adopted and will be implemented starting with the 2000 budget.

24. Monetary policy will continue to aim at controlling inflation and keeping foreign exchange reserves at a satisfactory level. Under the program, the increase in the money supply will be limited to 10 percent in 2000 , while the increase in base money is set at 8.7 percent. An accumulation of US $\$ 25.5$ million in net reserves of the BCRG is anticipated and claims on the government should decline by GF 24 billion. On this basis, the private sector could benefit from an 9 percent increase in banking system credit. In order to achieve its net foreign assets target for 2000 , the BCRG has established monthly benchmarks and proposes to intervene in the foreign exchange auction market, as needed, to observe them.

25. The BCRG is committed to maintaining a floating exchange rate regime without any intervention by the authorities, except to achieve the net foreign assets targets of the BCRG. In this context, the BCRG is aware that it is important for the foreign exchange auction market (MED) to operate without impediment. After having tried various auction modalities, the BCRG finally adopted a marginal price Dutch auction system which will be maintained until at least the midterm review. The BCRG will closely monitor the auction in order to avoid any collusion between participants. It will try to expand the number of participants. In addition, it will regularly monitor the reserve position of banks and will take all necessary steps to ensure compliance with the existing regulations. The BCRG will take necessary actions to ensure that foreign exchange of the public enterprises will be sold in the MED. Finally, it raised minimum interest rates on remunerated deposits in December 1999.

26. The BCRG will continue to strengthen its management and supervision of banks and credit institutions. As a first step, there will be an audit of the BCRG accounts by an international firm. The new chart of accounts for commercial banks will become effective on January 1,2001. To allow for more regular monitoring of banking activity, the BCRG's bank inspection department will produce a monthly report on compliance with banking regulations (exchange position and required reserves, internal auditing, and insider-lending) beginning on October 1, 1999. Furthermore, to enable banks to develop in an environment of fair competition, the special tax agreements under which they operate will be harmonized. The BCRG will produce, for the IMF, a memorandum on the effort to establish a concordance between national banking legislation and the Basle Committee principles by March 31, 2000. By June 30,2000, a draft law covering microcredit institutions, for which new regulations will be formulated. The Crédit Mutuel de Guinée will be fully recapitalized by January $31,2000$.

\section{B. Structural Policies}

27. The government is determined to pursue structural reforms to improve its administration and to create an enabling environment for private sector development. In 
addition to the measures already listed to improve fiscal and tax management and the health of the banking system, structural reforms will be pursued also in the public enterprise sector. The government is determined to reduce government participation in the productive sector to the benefit of the private sector. To this end, with donor assistance, it is preparing a reform program that focuses on liberalizing the economic environment and improving the incentive framework for private sector development. With donor assistance, the government has reviewed the 63 public enterprises to assess their viability and has decided: (a) to liquidate by June 30, 200012 enterprises that have ceased their activities and that are almost all wholly state-owned (AGRIMA - Trade, APILEC - Agro-industry, EGUMAT - Trade, FRUITEX Industrial, OCR - Trade, ONACIG - Cinema, SIAG KASSA - Industry, SOMIDRAT Transport, SOPAG - Industry, SOPRAG - Industry, UNICO - Industry, and ENELGUI Electricity); and (b) to reduce government participation in 7 enterprises in which it still has a minority shareholding and which would have been deemed viable by end-July 2000 (SGH Services, SOGUICO - Construction, SOGUILUBE - Industry, SOGUIRUSSE - Mining, SOPROCHIM - Industry, UGAR - Insurance, SOMIAG - Trade). For the others, the government will work out an action plan with the donors that best responds to its concern for divestment and safeguarding the public interest. The government will examine the law on privatization and regulations in the area of bankruptcy and liquidation with a view to ensuring an effective liquidation process.

28. Reorganization of the Natural Social Security Fund (CNSS) will continue with actions aimed at establishing its viability (an actuarial study) and measuring its receipts (updating the contributor file and determining outstanding balances, for which a collection plan will be prepared and implemented). In addition, the reorganization of the financial and accounting departments, begun in 1999 , will be completed by June 2000 . Lastly, the reliability of its accounts will be improved by the production of yearly accounts for the preceding financial year, and their certification by a firm of independent auditors before June $30,2000$.

29. The reforms undertaken to improve the performance of the judiciary, which is a priority sector, will be deepened with the assistance of Guinea's development partners. Draft laws reforming the status of the magistrates, notaries, auctioneers, and bailiffs will be submitted to the National Assembly for adoption at the next session (April 2000). The prison administration will be reorganized and prison management improved, taking into account its current weaknesses and the increase in the prison population.

\section{Governance}

30. The government is resolved to continue the struggle against corruption and further improve governance. It has already initiated several actions aimed at halting the misuse of public monies and intends to conclude them as soon as possible, including auditing the payment of duties and taxes by four public enterprises-the Port of Conakry, SOGEL, SOTELGUI, and SEEG. A decision on the reform of ANATM (the National Agency for Developing Mining Infrastructure) and an action plan will be presented to the IMF and the World Bank by March 31, 2000. By December 1999, the government will also put in place a 
committee to combat corruption, which will be responsible for coordinating the actions to be undertaken in this area.

\section{External Sector}

31. The balance of payments will be most affected by the rapid growth of gold exports (17.4 percent and 22.7 percent annually, in 1999 and 2000, respectively) mainly reflecting recent investments in the gold sector. Bauxite and aluminum will continue to represent more than half the value of exports but will grow at a lesser rate, in value terms. The evolution of imports will reflect the increase in the volume of imports of intermediate and capital goods, which is closely linked to investment in the public sector and mining, and the higher prices for petroleum products. The latter is an important factor in the estimated 6.7 percent deterioration in the 1999 terms of trade. The current account deficit (excluding official transfers) should rise from 5.9 percent of GDP in 1998 to 6.3 percent of GDP in 2000. During the period 1999-2000, public debt amortization should exceed capital inflows; however, the authorities are hoping to reschedule part of the debt in the context of an extension of the 1997 Paris Club agreement and a possible rescheduling of the Russian and Chinese debts. An agreement with Russia and with non-Paris-Club creditors should also make it possible to eliminate the stock of reschedulable arrears as at December 31, 1998, estimated at US\$0.5 billion.

32. Guinea's monitoring of its external debt improved over the course of the past few months on account of reforms implemented in the Debt and Investment Division (DDI), which was recently charged to the National Public Debt Directorate (NPDD). Additional progress is required in harmonizing the NDD's database with those of the donors, and in enhancing the software currently used, a task for which financing is being sought.

\section{E. Program Monitoring}

33. In quantitative terms, program implementation will be monitored according to the performance criteria set for end-March 2000 as well as the benchmarks for end-December 1999. Indicative benchmarks will also be set for end-June and end-September 2000 (see Table 1). Performance criteria and updated benchmarks for end-June and end-September 2000 will be set at the time of the midterm review. The structural benchmarks and structural performance criteria are shown in Table 2. The nonaccumulation of new external payment arrears is a performance criterion that will be applied on a continuous basis. Program implementation and the economic results recorded in connection with program targets will be subject to reviews by Fund staff in accordance with the third annual arrangement under the ESAF. The attainment of the BCRG's targets in regard to net foreign assets will be monitored monthly. Any deviation from these net foreign assets targets will trigger a consultation with Fund staff. The second disbursement under this arrangement will be conditional upon observance of the quantitative and structural performance criteria for end-March 2000 and completion of the first review before end-June 2000 . The first review will focus on the conduct of exchange rate policy and the progress in reforming customs. The third disbursement will be conditional upon observance 
of the quantitative and structural performance criteria for end-September 2000 and completion of the second review before December 2000 .

34. During the period of implementation of the third annual arrangement under the ESAF, the Guinean government will not, without Fund approval, introduce new or raise existing exchange restrictions, introduce or intensify any multiple currency practice, impose or intensify import restrictions for balance of payments reasons, or conclude bilateral payments agreements which are inconsistent with Article VIII. 
Table 1. Guinea: Quantitative Performance Criteria and Benchmarks Under the Third Annual ESAF Arrangement, 1999/2000

\begin{tabular}{|c|c|c|c|c|c|}
\hline & \multirow{2}{*}{$\begin{array}{l}1999 \\
\text { Sep. } \\
\text { Est. }\end{array}$} & \multicolumn{4}{|c|}{$1999-2000$} \\
\hline & & $\begin{array}{r}\text { Dec. } \\
1999 \\
\text { Indicative } \\
\text { Benchmark }\end{array}$ & $\begin{array}{r}\text { March } \\
2000 \\
\text { Perf. } \\
\text { Crit. }\end{array}$ & $\begin{array}{r}\text { June } \\
2000 \\
\text { Indicative } \\
\text { Benchmark }\end{array}$ & $\begin{array}{r}\text { Sep. } \\
2000 \\
\text { Indicative } \\
\text { Benchmark }\end{array}$ \\
\hline Central government primary balance (floor) $1 / 2 /$ & 84 & 123 & 158 & 195 & 236 \\
\hline Net bank credit to the government (ceiling) $3 / 4 / 11$ / & 143 & 141 & 141 & 128 & 117 \\
\hline Reserve money (ceiling) $5 /$ & 267 & 283 & $\begin{array}{l}287 \\
\text { dollars, e }\end{array}$ & nd of period) & 299 \\
\hline Net foreign assets of the central bank (floor) $6 / 7 / 11 /$ & 75.4 & 84.2 & 88.2 & 100.0 & 108.6 \\
\hline \multicolumn{6}{|l|}{$\begin{array}{l}\text { New nonconcessional medium or long-term external loans } \\
\text { contracted or guaranteed by the government or the central }\end{array}$} \\
\hline $\begin{array}{l}\text { Short-term external debt outstanding contracted or guaranteed } \\
\text { by the government or the central bank (ceiling) } 8 /\end{array}$ & 0 & 0 & 0 & 0 & 0 \\
\hline Outstanding external payments arrears (ceiling) $9 /$ & 0 & 0 & 0 & 0 & 0 \\
\hline · & \multicolumn{5}{|c|}{ (In billions of Guinean francs, end of period) } \\
\hline $\begin{array}{l}\text { Central government nonmining revenue } 2 / 10 / \\
\text { Of which }\end{array}$ & 297 & 408 & 531 & 665 & 787 \\
\hline Customs revenue $2 /$ & 204 & 281 & 370 & 459 & 546 \\
\hline Central government noninterest current expenditure $1 / 2 / 10 /$ & 277 & 356 & 456 & 567 & 659 \\
\hline Domestic arrears clearance $2 / 10 /$ & -2 & 20 & 19 & 16 & 19 \\
\hline Memorandum item: & & & & & \\
\hline Nonproject external financial assistance $2 / 9 /$ & 0 & 18 & 24 & 47 & 53 \\
\hline
\end{tabular}

$1 /$ On a commitment basis; the domestic primary balance is defined as the difference between total revenue (excluding grants) and noninterest domestic expenditure (excluding foreign-financed capital expenditure).

2/ Cumulative from the beginning of 1999.

3/ Excluding government paper issued in counterpart of the revaluation of the stock of gold (GF 17.6 billion).

4/ To be adjusted downward/upward for any lower/higher cash settlement of domestic arrears than indicated.

S/ To be adjusted downward for any reduction in, or shortfall in compliance with, the legal reserve requirement (11 percent of bank deposits).

6/ For purposes of the program, during 2000, gold will be valued at the U.S. dollar price agreed for end-December 1999.

$7 /$ To be adjusted upward for any new accumulation of external payments arrears, or cash settlement of such arrears inferior to program projections.

8/ Excluding commercial credits.

9/ Excluding arrears under negotiation with creditors, on a continuous basis.

10/ Does not constitute a performance criterion for end-March 2000.

11/ December ceiling (floor) adjustable upwards (downwards) by an amount equivalent to the shortfall (excess) in nonproject extemal financial assistance.

12/ Revenue at end-September does not include an amount of GF 11 billion of customs receipts arising mainly from compensations not recorded in government accounts. 
Table 2. Guinea: Structural Measures

( $*$ Performance Criterion)

Test Date

Public Finances

Monthly treasury balances.

Beginning February 15, 2000

(*) Preliminary balance. Final balance.

15 days after the end of the month

At the end of the following month

Computerized expenditure system

$\left(^{*}\right)$ Functioning of the system at the Ministry of Finance. January 15, 2000

Functioning of the overall system.

June 30,2000

Customs reform

Signature of contract with preshipment inspection company.

(*) Publishing of customs clearance procedures at airport.

December 15, 1999

March 31, 2000

\section{Banking and Financial Sector}

Audit of the BCRG.

Issuing of the request for bids.

(*) Beginning of audit.

Recapitalization of the Crédit Mutuel.

Draft of harmonized specialized tax agreements for commercial banks.

Monthly report on the observance of banking regulations (foreign exchange, required reserves, internal control, insider credit).

Public Enterprise Reform

Liquidation of 12 enterprises (see paragraph 26).

June 30,2000

(*) Decision on and an action plan for reform of ANAIM. CNSS

- Update list of contributors.

December 31, 1999

March 31, 2000

January 31,2000

December 31, 1999

Beginning October 31, 1999

- Determine overdue payments and action plan for recovery.

- Actuarial study.

March 31, 2000

June 30,2000

June 30,2000

June 30,2000

Governance

(*) Establishment of an anti-corruption committee.

December 31, 1999 
Table 3. Customs Reform Timetable

1. Fixing of revenue quotas for all domestic units, with sanctions if not fulfilled.

2. Strengthening ex post controls on customs clearance with fixed performance quotas, and sanctions if latter not fulfilled.

3. Revision of gasoline quotas to enterprises that are exempt from or subject to special rates or special delivery controls.

4. Fixing of revenue quotas for surveillance units fighting fraud, with sanctions if not fulfilled.

5. Periodic internal audits of all units.

6. Immediate prohibition of all emergency customs clearance procedures.

7. For all petroleum imports, require full payment of taxes with ex post refund for any exemptions.

8. Thorough examination and reform of all exemptions granted under the mining and investment code.

9. Restructuring of the customs division in charge of exemptions to separate study, clearance, and export control functions.

10. a) Instruction to hold merchandise imports when importer owes back taxes.

b) Application of new rules.
November 20, 1999 (Done)

November 20, 1999 (Done)

December 31, 1999

November 20, 1999 (Done)

Each quarter, beginning

December 1, 1999

Done

January 1,2000

Beginning in December 1999 for application in January 2000

Done

November 30, 1999 (Done)

December 1, 1999 (Done) 


\section{Guinea: Social Development}

Guinea is one of the poorest countries in the world. Although estimated per capita GNP of US\$550 in 1997 is above the sub-Saharan average of US\$510, social indicators remain extremely weak (Table 8), and the country is continuously ranked low, if not lowest, on the scale of the UNDP's Human Development Index. An integrated household survey, conducted in 1994, revealed that at least 40 percent of the population live in extreme poverty. Access to basic and vocational education, functional literacy programs, and basic and preventive health services is extremely limited, particularly in remote areas.

Any social development strategy in Guinea has to focus on the agricultural sector, as all empirical analysis suggests that poverty is highly concentrated in the rural areas. In addition, most agricultural activity takes place in the informal sector, so that production is only for local consumption and interregional markets are not developed. Thus, the potential for agriculture development to meet Guinea's nutrition needs is not exploited, and the country has become a net food importer.

Some steps have already been taken to integrate the rural sector systematically into the rest of the economy and provide basic services to the most vulnerable groups by decentralized capacity building. For example, local government districts have been established and implicated in local development. Community-based associations (NGOs, cooperatives, and others) developed strongly, after relevant regulations were relaxed. Over the last few years, resources have increasingly been channeled into these organizations, and fiscal decentralization continues to rank high on the government's agenda, in order to ensure an active participation of the rural population in the development process.

In 1994, the Guinean government launched the Human Development Initiative to foster social development in Guinea. This initiative was supported by the UNDP, the World Bank and several donors, and serves as a pilot initiative for sub-Saharan Africa. Based on an indepth analysis of the poverty situation, a National Human Development Program was developed, which has two main objectives: to improve governance and mitigate poverty. In order to improve governance, the program concentrates on three main components:

(i) strengthening government institutions conducting macroeconomic policy; (ii) developing civil society and decentralized structures; and (iii) establishing an institutional body to coordinate development policies. As to poverty alleviation, the program aims at improving access to basic services and at satisfying basic needs in certain rural pilot zones. Also, it emphasizes development of rural infrastructure and augmentation of agricultural output. Finally, the poverty eradication program aims at improving living conditions of the urban population.

As a result of the various government programs, health and education services improved significantly during the last few years. An education sector adjustment program was launched in 1990, which led to continued classroom construction and enhancement of school equipment and improvement of teaching quality. As a result, the gross school attendance rate rose from 28 percent in 1989 to over 50 percent in 1997. Establishment of local community literacy and vocational literacy training centers helped increasing the adult functional literacy rate from 28 percent in 1984 to 33 percent in 1995. In order to raise school attendance by 
girls, a committee on gender equity was established in 1994. It helped sensitize communities, local authorities and religious leaders on this issue, which had been given low priority. These activities translated into a doubling of school attendance by giris between 1991 and 1996. To improve access to health services, most of the country's hospitals were renovated and 349 health centers were constructed, mostly built by community groups, with technical assistance from local health districts. Government health coverage rose to 80 percent of the population in 1997.

Despite these achievements, there are still many constraints which seriously hamper development activities from having their full impact. Overall participation of the rural population in the political decision-making process is still weak, which can lead to a mismatch between the services provided and de facto priority needs. The responsibilities of rural communities as opposed to those of local representatives of central government are not clear; management skilis of staff is poor; and tax collection at the local level is low, with state funding being an irregular source of income. In addition, sectoral programs were often not well integrated in the past, and not in line with other programs and projects.

To tackle these problems, a National Consultation Forum, which brought crucial community development players and national decision-makers together, took place in Conakry in 1998. Prior to the meeting, a consultation exercise to develop a national strategic vision with a strong commitment to getting measurable results had been conducted in a highly participatory fashion. In all five regions of the country, consultations had been carried out in the form of community group meetings, so that almost a third of the whole population was represented. In addition, 3,380 persons, out of which a third women, had been individually interviewed. As a key outcome, five key broad priority areas were identified, i.e. education, health, rural development, infrastructure, and governance. The forum reached consensus on a results-oriented action plan. Performance targets and responsibilities were identified as benchmarks to measure progress, transparency, and accountability in achieving agreed priorities. Such benchmarks will serve as basis for dialogue between the government and the citizenry over achievements, and as orientation for the government's medium-term expenditure program in the future. Testing of service delivery under improved institutional arrangements will be carried out in four prefectures and 24 rural development communities. In addition to building measurement and analytical capacities, another important element of the results-based service delivery system are introduction and implementation of budget and expenditure tracking. The idea is to gauge the extent to which public resources reach the facility level, by means of a field survey, in order to measure the government's commitment to decentralization.

Guinea's long-run development strategy is spelled out in a long-term perspective paper entitled "Guinea-Vision 2010," developed in 1996. Therein, the government commits itself to invest in human capital and promote good governance. A Village Communities Support Program, supported by the World Bank, is scheduled to be implemented in 1999 and will further strengthen local governance in rural Guinea by promoting social and economic empowerment of the rural population, including vulnerable groups. Local communities and their representative local governments will be able to identify, implement and manage their own infrastructure and service needs. 


\section{Guinea: Relations with the Fund}

(As of September 30, 1999)

I. Membership Status: Joined September 28, 1963; Article VIII

II. General Resources Account:

Quota

Fund holdings of currency

Reserve position in the Fund

III. SDR Department

Net cumulative allocation

Holdings

IV. Outstanding Purchases and Loans

Enhanced Structural Adjustment Facility

(ESAF) arrangements
SDR million

107.10

107.10

0.08

SDR million

17.60

3.00

SDR million

86.57
Percent of quota

100.0

99.9

0.1

Percent of quota

100.0

17.1

Percent of quota

80.8

V. Financial Arrangements

\begin{tabular}{lcccc}
\multicolumn{1}{c}{ Type } & $\begin{array}{c}\text { Approval } \\
\text { Date }\end{array}$ & $\begin{array}{c}\text { Expiration } \\
\text { Date }\end{array}$ & $\begin{array}{c}\text { Amount Approved } \\
\text { (SDR million) }\end{array}$ & $\begin{array}{c}\text { Amount Drawn } \\
\text { (SDR million) }\end{array}$ \\
ESAF & $01 / 13 / 1997$ & $01 / 12 / 2000$ & 70.80 & 47.20 \\
ESAF & $11 / 06 / 1991$ & $12 / 19 / 1996$ & 57.90 & 46.32 \\
SAF & $07 / 29 / 1987$ & $07 / 28 / 1990$ & 40.53 & 28.95
\end{tabular}

VI. Projected Obligations to the Fund: (SDR million; based on existing use of resources and present holdings of SDRs)

$\begin{array}{lcccccc} & \begin{array}{c}\text { Overdue } \\ 09 / 30 / 1999\end{array} & 1999 & 2000 & \text { Forthcoming } \\ \text { Principal } & 0.0 & 1.7 & 6.1 & 9.3 & 8.7 & 11.7 \\ \text { Charges/interest } & 0.0 & 0.4 & 0.9 & 0.9 & 0.9 & 0.8 \\ \text { Total } & 0.0 & 2.1 & 7.0 & 10.2 & 9.6 & 12.5\end{array}$




\section{Exchange Rate Arrangement}

Guinea has a floating exchange rate. The official exchange rate of the Guinea franc is determined weekly in the auction market for foreign exchange. On September 30, 1999, the official rate of Guinea franc was GF 1,436 per U.S. dollar. Commercial banks and foreign exchange bureaus are free to buy and sell foreign exchange at any rate.

\section{Article IV Consultations}

Guinea is on the regular 12-month cycle; the last consultation was concluded by the Executive Board on April 3, 1998 (EBS/98/54; 3/20/98).

\section{Technical Assistance}

MAE is currently providing to the Central Bank of the Republic of Guinea a principal advisor to the Governor. An STA technical assistance mission visited Conakry in early 1994 to review monetary and government finance statistics and the modalities for establishing the International Financial Statistics page for Guinea, which was published for the first time in June 1995. Another STA technical mission visited Conakry in May 1995 to help in the compilation of balance of payments statistics. Three FAD technical assistance missions visited Conakry in recent years: in April-May 1994 to review the Guinean tax system and make recommendations on the tax reform needs, particularly in the areas of tax administration and indirect taxation; and in January 1997 to review implementation of the value-added tax and make recommendations to improve revenue performance in view of the large shortfall experienced in 1996. An FAD mission on customs reform visited Conakry in March 1999. An FAD advisor on tax administration was posted between April 1995 and September 1997 as advisor to the Minister of Finance. An FAD technical assistant on treasury management was posted in Conakry from January to June 1999. Another technical assistant on customs reform is in Conakry from September to December 1999.

\section{Resident Representative}

Mr. Le Bouder's appointment as the Fund's Senior Resident Representative in Conakry was renewed on October 1, 1999 for a third year. 


\section{Guinea: Relations with the World Bank Group}

(As of September 30, 1999)

1. The main thrust of the World Bank's Country Assistance Strategy for fiscal year (FY) 98-FY 2000 is to improve governance and institutional capacity, to enhance service delivery for poverty reduction, and to promote broadly based and equitable growth with a focus on the rural sector. This strategy is designed to put Guinea back on track toward financial viability and sustainable economic growth by redressing imbalances in the government's finances, thus making it possible to redirect the country's resources to the priority sectors, and by furthering structural reforms that will progressively eliminate the obstacles currently hampering the development of the private sector.

2. As of September 30,1999, total World Bank commitments to Guinea amounted to US $\$ 1,221.43$ million, of which US $\$ 1,093.75$ million had been disbursed. Over the threeyear period covering FY 99-FY 2001, the Bank's lending program will be approximately US\$228.4 million. The IFC's portfolio totals three projects, with total commitments of US\$9.2 million (fully disbursed).

3. Recent and proposed Bank Group projects have a broad sectoral coverage. In recent years, the World Bank has been active in: rural development, education, mining, financial sector, and public expenditure management. In the next three years, the Bank's assistance will also aim at improving service delivery for poverty reduction, with projects in health and nutrition, improving urban services and promoting rural development. An upcoming structural adjustment operation (SAC IV) will help to consolidate the progress achieved under the previous public expenditure management credit (PEMAC). In addition, the new operation will accompany the government's efforts in the areas of public enterprise reform and governance improvement and corruption control. The Bank will also provide support for institutional strengthening and capacity building, with a focus on enhancing the government's efficiency as a provider of basic public services.

4. In addition to its projects, the Bank will support nonlending activities to assist planned lending operations, deepen the reforms in public expenditure management, define its approach to rural development, and strengthen the governance/capacitybuilding approach to civil service reform. Nonlending activities will also play a greater role in helping to address specific strategic and capacity-building issues, ensure an active policy dialogue, and build consensus and partnership within the country and with key institutions and donors actively involved in Guinea. 
IBRD/IDA Operations ${ }^{1}$

(1995-2001)

\begin{tabular}{|c|c|c|c|c|c|c|c|}
\hline & 1995 & 1996 & 1997 & 1998 & 1999 & 2000 & 2001 \\
\hline \multirow{3}{*}{ Commitments, total } & \multicolumn{7}{|c|}{ (In millions of U.S. dollars) } \\
\hline & 65.5 & 53.8 & 25.0 & 70.0 & 55.4 & 78.0 & 95.0 \\
\hline & \multicolumn{7}{|c|}{ (In percent of total commitments) } \\
\hline \multicolumn{8}{|l|}{ By sector } \\
\hline Agriculture & 0.0 & 65.1 & 0.0 & 0.0 & 39.7 & 0.0 & 0.0 \\
\hline Finance & 0.0 & 0.0 & 0.0 & 0.0 & 0.0 & 0.0 & 15.8 \\
\hline Education & 64.9 & 12.3 & 0.0 & 0.0 & 7.4 & 19.2 & 0.0 \\
\hline Energy & 0.0 & 0.0 & 0.0 & 0.0 & 0.0 & 3.9 & 0,0 \\
\hline Mining & 0.0 & 22.7 & 0.0 & 0.0 & 0.0 & 0.0 & 0.0 \\
\hline Multisector & 35.1 & 0.0 & 0.0 & 100.0 & 0.0 & 51.3 & 0.0 \\
\hline Population & 0.0 & 0.0 & 0.0 & 0.0 & 20.4 & 0.0 & 31.6 \\
\hline Public sector management & 0.0 & 0.0 & 0.0 & 0.0 & 0.0 & 25.6 & 31.6 \\
\hline Transports & 0.0 & 0.0 & 0.0 & 0.0 & 0.0 & 0.0 & 0.0 \\
\hline Urban development & 0.0 & 0.0 & 0.0 & 0.0 & 32.5 & 0.0 & 0.0 \\
\hline Water supply and sanitation & 0.0 & 0.0 & 100.0 & 0.0 & 0.0 & 0.0 & 21.0 \\
\hline Total & 100.0 & 100.0 & 100.0 & 100.0 & 100.0 & 100.0 & 100.0 \\
\hline \multicolumn{8}{|l|}{ By lending instrument } \\
\hline Projects & 35.1 & 0.0 & 0.0 & 100.0 & 100.0 & 100.0 & 100.0 \\
\hline Adjustment loans & 64.9 & 100.0 & 100.0 & 0.0 & 0.0 & 0.0 & 0.0 \\
\hline \multirow[t]{2}{*}{ Total } & 100.0 & 100.0 & 100.0 & 100.0 & 100.0 & 100.0 & 100.0 \\
\hline & \multicolumn{7}{|c|}{ (In millions of U.S. dollars) } \\
\hline Disbursement, total & 67.8 & 60.6 & 56.6 & 68.3 & 50.7 & 46.3 & 33.9 \\
\hline Project loans & 57.4 & 46.6 & 56.1 & 15.4 & 24.3 & 26.3 & 93.9 \\
\hline Adjustment loans, total & 10.4 & 14.0 & 0.5 & 52.9 & 26.4 & 20.0 & 20.0 \\
\hline Financial sector adjustment credit & 10.4 & 14.0 & 0.5 & 9.3 & 0.0 & 0.0 & 0.0 \\
\hline Structural adjustment credit (SAC III) & 0.0 & 0.0 & 0.0 & 43.6 & 26.4 & 0.0 & 0.0 \\
\hline Structural adjustment credit (SAC IV) & 0.0 & 0.0 & 0.0 & 0.0 & 0.0 & 20.0 & 20.0 \\
\hline
\end{tabular}

\footnotetext{
' Fiscal year ending June 30 .
} 


\section{Guinea: Statistical Issues}

1. Although substantial improvements have been made in recent years in the availability of detailed government finance, monetary accounts, and balance of payments statistics, some problems remain, in particular in the compilation of real sector statistics. The authorities are aware of the shortcomings of the statistical information and intend to effect significant improvements, especially in the areas of national accounts, prices, the balance of payments, and external debt statistics, but require substantial technical assistance.

\section{Real sector statistics}

2. After extensive work in 1987-88 to build a solid database for the national accounts, with technical assistance from the World Bank and France, final data for 1986 and provisional data for 1987 were produced; however, major delays were encountered in the preparation of national accounts data for subsequent years. Updated national accounts estimates for 1986-90 were provided to the staff in late 1993 by the National Accounts Statistics Division of the Ministry of Planning, covering mainly the composition of GDP, with limited information on expenditure aggregates. These data are subject to some methodological weaknesses, in particular with regard to the compilation of industrial deflators and the estimates of activity in the informal sector. Provisional national accounts estimates for 1991-95, compiled by the Economic Analysis Division (EAD) of the Ministry of Planning, were also provided to the Fund staff in early 1996. A quarterly report is prepared by the EAD on the economic developments that includes regular updates of its national accounts estimates and projections for the period ahead. The authorities have a long-standing request to STA for technical assistance on national accounts.

3. The consumer price index for Conakry is available on a monthly basis, with onemonth lag. Export prices are estimated on the basis of information supplied directly by the mining companies, while import prices are based on a weighted average of partner countries' export prices. Exchange rates are reported weekly.

4. As regards production statistics, no detailed figures are available, and data on the agriculture sector have been published only sporadically in the form of Food and Agriculture Organization/United Nations Development Program surveys. No data on employment or labor costs are available.

\section{Balance of payments statistics}

5. The authorities have implemented some of the recommendations made by a balance of payments statistics mission in May 1995. Notably, coverage of trade in services, private transfers, and capital flows has been expanded by surveying service providers and large companies on an annual basis. However, the survey is not comprehensive as there is no penalty on noncompliance. In view of the difficulties encountered with the compilation of annual statistics, the mission's recommendation to compile data on a quarterly basis has not yet been implemented. 
6. Merchandise trade statistics are reported in the standard Harmonized System of Customs Classification, net of imports by diplomats and transit trade. In spite of the technically advanced method of presentation, the presented data are clearly inconsistent with actual developments in the country. Some of these inconsistencies may be due to smuggling, as exports of gold and diamonds are subject to modest export taxes and imports are subject to import duties. However, the trade statistics also report significant exports of aluminum products, which are, according to the Ministry of Mining and Energy, not produced in the country. Thus the data are substantially adjusted prior to publication.

7. The balance of payments statistics also affect the national accounts data prepared by the Ministry of Planning. The national accounts are based on trade data that include transit trade and imports by diplomats, thus overestimating the openness of the economy. However, the national accounts use estimates of trade in services, which are well below those estimated on the basis of the surveys conducted by the central bank. The authorities have requested additional technical assistance for STA for balance of payments statistics.

\section{Government finance statistics}

8. Comprehensive monthly budgetary data have been compiled by the Ministry of Finance on a cash basis for government revenue and on a commitment and cash basis for government expenditure; AFR staff receives data with one-month delay. Estimates for consolidated central government operations are made on the basis of treasury data. Budgetary data are often not internally coherent, and considerable work needs to be done to improve the quality of government finance statistics. This year, the Ministry of Economy and Finance resumed reporting data for publication, in the 1999 GFS Yearbook. Final data were provided for 1998 and forward estimates for 1999. Before the latest submission, the most recent data for Guinea were for 1992 and the country page was dropped from the 1998 GFS Yearbook.

\section{Monetary accounts statistics}

9. Monthly data on monetary authorities and deposit money banks are available However, the timeliness of data reporting for IFS publication has recently deteriorated from two months to 12 months lag. The monetary authorities' statistics are comprehensive and generally reliable. Although efforts are being made to strengthen the commercial banks' accounting practices, in particular the classification of nonperforming loans, the quality of deposit money banks' data is still weak. 


\section{Guinea: Core Statistical Indicators}

(As of end-October 1999)

\begin{tabular}{|c|c|c|c|c|c|c|c|c|c|c|}
\hline $\begin{array}{c}\text { Exchange } \\
\text { Rates }\end{array}$ & $\begin{array}{c}\text { International } \\
\text { Reserves }\end{array}$ & $\begin{array}{l}\text { Central Bank } \\
\text { Balance Sheet }\end{array}$ & $\begin{array}{c}\text { Reservel } \\
\text { Base Money }\end{array}$ & $\begin{array}{l}\text { Broad } \\
\text { Money }\end{array}$ & $\begin{array}{c}\text { Interest } \\
\text { Rates }\end{array}$ & $\begin{array}{l}\text { Consumer } \\
\text { Price Index }\end{array}$ & $\begin{array}{l}\text { Exports/ } \\
\text { Imports }\end{array}$ & $\begin{array}{l}\text { Current } \\
\text { Account } \\
\text { Balance }\end{array}$ & $\begin{array}{c}\text { Overall } \\
\text { Government } \\
\text { Balance }\end{array}$ & $\begin{array}{c}\text { External } \\
\text { Debt }\end{array}$ \\
\hline
\end{tabular}

Date of latest

observation

Date received

Frequency of data $1 /$

Frequency of

reporting $1 /$

Source of data $2 /$

Mode of reporting $3 /$

Confidentiality $4 /$

Frequency of

publication $1 /$

\begin{tabular}{|c|c|c|c|c|c|c|c|c|c|c|c|}
\hline $10 / 27 / 99$ & $9 / 30 / 99$ & $9 / 30 / 99$ & $9 / 30 / 99$ & $9 / 30 / 99$ & $9 / 30 / 99$ & $9 / 30 / 99$ & $12 / 98$ & 1998 & $9 / 30 / 99$ & 1998 & 1998 \\
\hline $10 / 28 / 99$ & $10 / 15 / 99$ & $10 / 15 / 99$ & $10 / 15 / 99$ & $10 / 15 / 99$ & $10 / 15 / 99$ & $10 / 20 / 99$ & $3 / 99$ & $3 / 99$ & $10 / 20 / 99$ & $5 / 99$ & $3 / 99$ \\
\hline $\mathrm{D} / \mathrm{M}$ & $\mathbf{M}$ & M & $\mathbf{M}$ & M & M & $\mathrm{M}$ & A & A & $\mathrm{M}$ & A & $Q$ \\
\hline $\mathrm{D} / \mathrm{M}$ & $\mathbf{M}$ & $\mathbf{M}$ & $\mathbf{M}$ & $M$ & $\mathbf{M}$ & $\mathbf{M}$ & A & A & $\mathbf{M}$ & A & $Q$ \\
\hline BCRG & BCRG & BCRG & BCRG & BCRG & BCRG & MOP & $\begin{array}{c}\text { Fund } \\
\text { Mission }\end{array}$ & $\begin{array}{l}\text { Fund } \\
\text { Mission }\end{array}$ & MEF & MOP & MEF \\
\hline $\mathrm{C} / \mathrm{M}$ & $\mathrm{C} / \mathrm{M}$ & $\mathrm{C} / \mathrm{M}$ & $\mathrm{C} / \mathrm{M}$ & $\mathrm{C} / \mathrm{M}$ & $\mathrm{M}$ & $\mathrm{C} / \mathrm{M}$ & V & V & $\mathrm{C} / \mathrm{M}$ & V & M \\
\hline $\mathrm{U}$ & $\mathrm{U}$ & $\mathrm{U}$ & $\mathrm{U}$ & $\mathrm{U}$ & U & $\mathrm{U}$ & $\mathrm{U}$ & $\mathrm{U}$ & U & $\mathrm{U}$ & $\mathrm{U}$ \\
\hline $\mathrm{D}$ & $\mathbf{M}$ & $\mathbf{M}$ & M & M & M & M & $\mathrm{M}$ & A & M & A & $Q$ \\
\hline
\end{tabular}

1/ $\mathrm{D}=$ daily; $\mathrm{M}=$ monthly; $\mathrm{Q}=$ quarterly; $\mathrm{A}=$ annual.

2/ $\mathrm{BCRG}=$ Central Bank of the Republic of Guinea; MEF = Ministry of Economy and Finance; MOP = Ministry of Planning.

3/ $\mathrm{C}=$ cable or facsimile; $\mathrm{M}=$ mail; $\mathrm{V}=$ staff visits/missions.

4/ $U=$ unrestricted. 


\section{INTERNATIONAL MONETARY FUND}

EXTERNAL

Public Information Notice

Public Information Notice (PIN) No. 00/18

FOR IMMEDIATE RELEASE

March 8, 2000

International Monetary Fund

$70019^{\text {th }}$ Street, NW

Washington, D.C. $2043 \uparrow$ USA

\section{IMF Concludes Article IV Consultation with Guinea}

On December 21, 1999, the Executive Board concluded the Article IV consultation with Guinea. $^{1}$

\section{Background}

Towards the end of 1998, the Guinean authorities confronted a numbers of serious shocks that were beyond their control. The global economic crisis resulted in a drop in demand for its main export products-alumina and bauxite. The deteriorating security situation in neighboring countries required increasing financial commitments to regional peacekeeping forces and continued expenditure to defend its own borders and host a refugee community between 5 and 10 percent of its population. These problems were aggravated by a drop off in commercial activity related to the presidential elections.

Together, these shocks constrained economic activity and posed difficult budgetary management problems. Real GDP in 1998 grew by 4.5 percent, compared to 4.8 percent in 1997 , with mining activity being sluggish and service sector growth slowing. On average, prices rose to 5.1 percent, compared to 1.9 percent in 1997. Government revenue was 10.6 percent of GDP, 0.7 of a percentage point lower than in 1997, with taxes on mining revenue and international trade being below expectations. Some of the revenue shortfall was compensated by curbing current expenditure, but the primary surplus fell to 2.4 percent of GDP, compared to 2.8 percent in 1997. Broad money grew by 6.1 percent; credit to the government declined by 3.5 percent of beginning-of-period money, and net foreign assets increased by 5.6 percent on the same basis. The Guinean franc depreciated by 13.4 percent in 1998 and the spread

\footnotetext{
${ }^{1}$ Under Article IV of the IMF's Articles of Agreement, the IMF holds bilateral discussions with members, usually every year. A staff team visits the country, collects economic and financial information, and discusses with officials the country's economic developments and policies. On return to headquarters, the staff prepares a report, which forms the basis for discussion by the Executive Board. At the conclusion of the discussion, the Managing Director, as Chairman of the Board, summarizes the views of Executive Directors, and this summary is transmitted to the country's authorities. In this PIN, the main features of the Board's discussion are described.
} 
between official and parallel rates widened. The current account deficit, excluding public transfers, narrowed from 6.3 percent of GDP in 1997 to 6.0 percent in 1998, thanks in part to the establishment of new gold mines. There was a sharp deterioration of the capital account, reflecting a fall in both public and private investment. In the face of budgetary difficulties, some 1998 debt payments were postponed, while other arrears occurred because of problems with the debt management system. All external arrears were cleared early in 1999.

The authorities made significant progress in restoring the health of the banking system. Restructuring agreements for two banks were signed in 1998; they have since been recapitalized by private shareholders and the government, and the restructuring of their operations have begun. However, the situation of a third bank remains precarious because the private shareholders have not yet supplied the additional capital. The government is continuing with the judicial proceedings to recover the bad loans of a fourth bank, which had been closed in 1997. The restructuring plan for the social security fund (CNSS) was adopted by the government in November 1998.

The problems encountered in late 1998 carried over into 1999. There was an expenditure overhang from 1998, resulting from weak budgetary controls and efforts to meet end-1998 budgetary targets. The initial 1999 budget counted on the success a peace settlement in Sierra Leone which did not hold. Thus, expenditures outstripped revenue in the first four months of 1999 , with credit to the government from the central bank and the money supply ballooning, and net foreign assets declining sharply. Recognizing the danger of the situation, the authorities adopted a new budget in the second quarter of 1999 with higher revenue from improved customs and tax administration and cuts in nonpriority expenditures. Substantial progress was made between end-April and end-September in restoring macroeconomic equilibrium, with credit to the government declining, the money supply stabilizing and some reaccumulation of net foreign assets. Notable progress has also been made regarding external debt-service payments; the government has been making all external debt service payments without any delay.

\section{Executive Board Assessment}

Executive Directors noted that the overall performance in 1999 had been mixed. Exogenous factors, in particular the fall in the price of bauxite and alumina and political instability in neighboring countries, had adversely affected economic growth and the macroeconomic situation. Directors commended Guinea for the important role it had played in regional peacekeeping, and noted the severe domestic budgetary pressures resulting from this intervention. Directors regretted the serious weaknesses in fiscal and monetary management that had exacerbated the effect of the adverse external developments on macroeconomic stability. While welcoming the prompt remedial actions taken to deal with slippages that had helped put the program back on track, they stressed that, nevertheless, considerable work remained to be done to establish a sound policy environment for sustained economic growth.

Directors underscored the importance of reinforcing fiscal discipline. They regretted the continuing weak revenue performance in 1999, and stressed the need to secure a durable 
improvement in revenue collection. To this end, they emphasized the need to widen the tax base. They welcomed the measures already taken to reform customs, but underscored the necessity for rigorous implementation and for further reform. In addition, Directors noted the importance of strict expenditure control, containing in particular the growth of the wage bill, especially in light of the high level of poverty and the need to increase spending on priority social sectors. Several Directors also stressed the need to improve fiscal transparency and strengthen budgetary procedures. In this connection, they underscored that off-budget spending must be avoided.

Directors stressed the need for a realistic exchange rate and noted that the authorities should allow the Guinean franc to float freely. While welcoming the establishment of the foreign exchange auction, they emphasized the need to deepen the auction by ensuring that parastatal foreign exchange continues to be sold in the auction. Directors welcomed the progress in the reform of the banking system, which they considered should continue, and also urged the authorities to proceed expeditiously with an audit of the central bank of Guinea.

Directors commended the authorities for initiating the reform of the social security fund and stressed the urgency of establishing a sound and transparent social security system for all Guinean workers. They also welcomed the continuing efforts to privatize public enterprises.

Directors observed that governance problems remain an important concern in Guinea. They welcomed the actions taken by the government to fight corruption, which would also be crucial for ensuring continued donor support. They urged the government to establish without delay the envisaged anticorruption commission, and to show its determination to eradicate corruption by dealing swiftly, firmly, and transparently with pending cases of corruption as well as any new cases that come to light. They stressed that such efforts would be facilitated by strengthening the justice system.

Directors expressed concern regarding the weak social indicators in Guinea despite the fact that per capita income is above the sub-Saharan African average. They stressed the importance of the govemment's formulating a comprehensive poverty reduction strategy, and of this being done through a broad-based and transparent participatory process.

Directors agreed that Guinea was eligible for assistance under the enhanced HIPC Initiative, with a decision point possible in 2000 , but underscored the importance of sustained program implementation under the Poverty Reduction and Growth Facility (PRGF) in this connection. They urged the authorities to prepare an interim poverty reduction strategy paper to be presented at the decision point, while work was ongoing in establishing a full-fledged framework for poverty reduction.

It is expected that the next Article IV consultation with Guinea will be held on the standard 12-month cycle. 
Public Information Notices (PINS) are issued, (i) at the request of a member country, following the conclusion of the Article IV consultation for countries seeking to make known the views of the IMF to the public. This action is intended to strengthen IMF surveillance over the economic policies of member countries by increasing the transparency of the IMF's assessment of these policies; and (ii) following policy discussions in the Executive Board at the decision of the Board. As part of a pilot project, the staff report (use the free Adobe Acrobat Reader to view this pdf file) for the 1999 Article IV consultation with Guinea is also available on the IMF's website (http://www.imf.org). 
Guinea: Selected Economic Indicators, 1997-2000

\begin{tabular}{|c|c|c|c|c|}
\hline & \multirow[b]{2}{*}{1997} & \multirow{2}{*}{$\begin{array}{r}\text { Est. } \\
1998\end{array}$} & \multicolumn{2}{|c|}{ Projections } \\
\hline & & & 1999 & 2000 \\
\hline & \multicolumn{4}{|c|}{ (Annual changes in percent) } \\
\hline \multicolumn{5}{|l|}{ Domestic economy } \\
\hline Changes in real GDP & 4.8 & 4.5 & 3.7 & 5.0 \\
\hline Changes in consumer prices (period average) & 1.9 & 5.1 & 4.5 & 5.8 \\
\hline & \multicolumn{4}{|c|}{ (In millions of U.S. dollars, unless otherwise indicated) } \\
\hline \multicolumn{5}{|l|}{ External economy } \\
\hline Exports, f.o.b. & 660.0 & 709.2 & 754.5 & 823.4 \\
\hline Imports, f.o.b. & -572.5 & -571.8 & -580.1 & -634.3 \\
\hline Current account balance, excluding official transfers & -244.2 & -227.4 & -216.6 & -225.1 \\
\hline (in percent of GDP) & -6.3 & -6.0 & -5.8 & -6.3 \\
\hline Capital account balance & 100.8 & 60.7 & 5.0 & 40.5 \\
\hline Gross official reserves & 225.5 & 248.0 & 220.1 & 257.6 \\
\hline (in months of imports) & 3.2 & 3.4 & 2.9 & 3.2 \\
\hline Debt service (including to the Fund) $1 /$ & 25.6 & 19.5 & 24.8 & 20.5 \\
\hline Change in real effective exchange rate (in percent) $2 /$ & -0.7 & -3.5 & -2.5 & ... \\
\hline & \multicolumn{4}{|c|}{ (In percent of GDP, unless otherwise indicated) } \\
\hline \multicolumn{5}{|l|}{ Financial variables } \\
\hline Government revenue & 11.2 & 10.6 & 10.4 & 11.5 \\
\hline Domestic primary balance $3 /$ & 2.8 & 2.4 & 2.4 & 2.7 \\
\hline Velocity (GDP/year-end M2) & 11.2 & 10.7 & 10.6 & 10.5 \\
\hline Interest rate 4 I & 9.0 & 9.0 & 9.0 & 9.0 \\
\hline
\end{tabular}

Sources: Guinean authorities; and IMF staff estimates and projections.

$1 /$ In percent of exports of goods and nonfactor services.

$2 /$ Increasing figures indicate an appreciation.

3/ Excluding external aid.

4/ Minimum annual rate on bank savings deposits. 